Revista de
Economild
Contemporâned

\title{
BRASIL: É UMA DEPRESSÃO, NÃO FOI APENAS UMA RECESSÃO
}

\author{
João Sicsu ${ }^{a}$

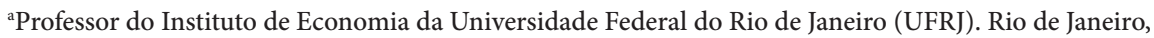 \\ RJ, Brasil. ORCID: https://orcid.org/0000-0003-3997-7129.
}

Artigo recebido em 08/06/2018 e aceito para publicação em 01/02/2019.

RESUMO: O objetivo do artigo é caracterizar a situação econômica brasileira atual e fazer a sua datação. O Brasil possui nos dias de hoje as principais características das depressões de 1870 e 1930. Naqueles episódios históricos, houve uma queda acentuada do produto, uma elevada taxa de desemprego e uma prolongada insuficiência de demanda. O Brasil, desde o final de 2013 e durante o ano de 2014, apresentou os primeiros sinais de uma recessão que poderia deslizar para uma depressão. Em 2015, mergulhou na depressão. A depressão é uma condição anormal da economia. Uma recessão seria uma condição normal da economia.

PALAVRAS-CHAVE: economia brasileira; depressão; economia keynesiana.

CLASSIFICAÇÃO JEL: E32; E23; E12. 


\title{
BRAZIL: IT'S A DEPRESSION, IT WAS NOT A RECESSION
}

\begin{abstract}
The purpose of this article is to characterize the current Brazilian economic situation and make its datation. Nowadays, Brazil has the main characteristics of the depressions of the 1870s and 1930s. During those events there was a sharp fall in output, a high unemployment rate and a prolonged insufficiency of demand. Brazil, since the end of 2013 and during the year 2014, presented the first signs of a recession that could slide off into depression. By 2015, it plunged into depression. Depression is an abnormal condition of an economy. A recession would be a normal economic condition.
\end{abstract}

KEYWORDS: Brazilian economy; depression; Keynesian economics. 


\section{INTRODUÇÃO'}

Será visível em meados de 1933 que essa queda é do mesmo tipo das quedas anteriores embora mais violenta, e está se superando pela operação das forças naturais e pela própria resiliência do sistema? [pergunta feita ao final de 1932] (KEYNES, 1982, p. 210)

A pergunta feita por Keynes na epígrafe não era para revelar uma dúvida que supostamente teria sobre a gravidade da Grande Depressão. Era uma tentativa de atrair a atenção daqueles que ainda tinham dúvidas sobre a seriedade daquele momento histórico. Mais de um ano antes, em março de 1931, ele já tinha afirmado: “o presente colapso, julgado pela queda dos preços e outros indicadores, é um dos mais violentos que já ocorreu na história econômica” (KEYNES, 1981, p. 519). Keynes também não acreditava na recuperação do sistema a partir de decisões privadas. Em março de 1930, diagnosticou que a causa principal da Depressão tinha sido a queda dos investimentos privados e que “esse gasto reduzido dos empresários não era equilibrado pelo gasto aumentado dos consumidores” (KEYNES, 1981, p. 480). Isso não seria possível porque o consumidor “[...] poupa pouco nos booms e poupa demais nas quedas" (1981, p. 480).

No seu clássico Business Cycles, publicado em 1939, Joseph Schumpeter afirmou que a configuração do ano de 1930 já podia ser considerada como "uma recessão deslizando para uma depressão" (SCHUMPETER, 1939, p. 14), mas que

os homens de negócio e os analistas, que no outono de 1929 avaliaram que nada pior estava à frente do que uma "recessão" não muito mais séria do que a de 1924, não ficaram muito decepcionados...[no primeiro semestre de 1930]. (SCHUMPETER, 1939, p. 911)

Schumpeter concluiu que, somente em 1932, dados os eventos repetidos de contração do produto, emprego e crédito dos anos anteriores, é que estaria de fato caracterizado um mergulho da recessão para a Grande Depressão.

Pairam nos dias de hoje as mesmas dúvidas e uma falta de reconhecimento sobre a gravidade da situação econômica. Há vozes isoladas. Paul Krugman e Joseph Stiglitz têm se destacado fazendo o diagnóstico da situação e propondo receituários. Segundo

1 O autor agradece os comentários de Antonio Licha. Como de praxe, eximindo-o de qualquer responsabilidade sobre o conteúdo do artigo. 
os dois prêmios Nobel, o mundo mergulhou em uma depressão a partir dos anos 2008-2009. O Brasil fez um extraordinário movimento de resistência naquele período e se livrou da avalanche depressiva. Contudo, acontecimentos posteriores fizeram com que a situação da economia brasileira mudasse para um quadro de enorme gravidade.

O objetivo deste artigo é caracterizar a situação econômica brasileira e fazer a sua datação. Tal caracterização é feita a partir da tradição teórica não convencional, ou seja, de forma específica, neste artigo, a partir das ideias de J. M. Keynes, J. Schumpeter, M. Kalecki e os contemporâneos J. Stiglitz e Paul Krugman. É constatado que o Brasil enfrenta uma depressão desde meados do ano de 2014.

Para se alcançar tal conclusão, na seção 2 é mostrado que importantes economias estão dentro de uma depressão (embora desde 2017-2018 em condições bem mais favoráveis), assim como são destacadas as semelhanças e diferenças em relação às depressões anteriores dos anos 1870 e 1930. Tal fenômeno é (sempre) internacional e o Brasil está inserido nesse grave problema. Na seção 3 são apresentados argumentos quantitativos para justificar o diagnóstico de gravidade do quadro brasileiro e é feita a datação da crise atual. Na seção 4 são adicionados aos argumentos empíricos alguns elementos teóricos e qualitativos para detalhar a análise sobre a economia brasileira atual. Na seção 5 são destacadas as causas da desaceleração e da recessão que levaram a economia brasileira para a depressão. Por fim, na seção 6 são feitas algumas considerações-síntese, entre elas que nem todo crescimento econômico dentro de uma depressão significa a aderência a uma trajetória de recuperação.

Cabe, ainda, uma observação. Em paralelo à apresentação de argumentos empíricos que sustentam a conclusão do artigo, foram apresentadas linhas gerais de uma teoria sobre o tema da depressão na medida em que não existe literatura sobre o tema. Sendo assim, o presente artigo pretende contribuir com a literatura econômica apresentando uma caracterização histórica e real para a economia brasileira, assim como delineando um esboço de teoria da depressão.

\section{A DEPRESSÃO NO MUNDO}

É reconhecido que a depressão é um fenômeno internacional. Em 1873 se revelou na Bolsa de Viena e se espalhou mundo afora. ${ }^{2}$ Em 1929, foi na Bolsa de Nova Iorque e

2 Dobb (1983, p. 223-224) descreveu o alcance da primeira depressão, além da Grã-Bretanha, nos Estados Unidos, Alemanha, Rússia e França. 
também atingiu o mundo. ${ }^{3}$ Contudo, ficaram evidentes que os canais de transmissão para cada economia são variados, que os efeitos em cada país são diferenciados, que o momento de entrada e o tempo de duração são não coincidentes entre os países atingidos e que existem causas nacionais específicas.

Hoje vivemos uma terceira grave crise. O ponto inicial mais evidente da crise, que já dura mais de dez anos, foi o anúncio da quebra do Banco Lehman Brothers em 15 de setembro de 2008. A crise se espalhou, como nas depressões anteriores. E, tal como em 1929, foi uma crise "made in USA", para usar uma expressão de Stiglitz (2010, p. 35). A resposta de governos e seus bancos centrais foi uma verdadeira operação de resgate de suas economias. Políticas monetárias e fiscais expansionistas, benefícios sociais e o seguro-desemprego agiram para impedir um mergulho profundo em cada país.

Um ano após a eclosão da crise, em setembro de 2009, a reunião de líderes do G-20 fez um balanço extremamente positivo das medidas sugeridas na reunião de meses antes, de abril:

A produção global contraía-se a um ritmo nunca visto desde os anos 1930. O comércio exterior estava em queda. Os empregos desapareciam rapidamente. Nossos povos tinham a preocupação de que o mundo estivesse à beira de uma depressão.

Naquela ocasião, nossos países concordaram a fazer tudo que fosse necessário para assegurar a recuperação, reparar os sistemas financeiros e manter o fluxo global de capital.

Funcionou.

Nossa resposta vigorosa ajudou a interromper o declínio agudo e perigoso da atividade global e estabilizou os mercados financeiros. (G-20 SUMMIT, 2009)

Apesar da avaliação positiva em relação às medidas adotadas, ainda havia preocupação dos líderes do G-20 com o desemprego e a retomada de uma trajetória de recuperação para níveis pré-crise. Nessa mesma Declaração reafirmaram o forte propósito de manter e reforçar as políticas que impediram a economia mundial de entrar em queda livre e, também, de buscar uma trajetória de recuperação. Constou na Declaração:

O processo de recuperação e reparação permanece incompleto. Em muitos países, o desemprego continua a taxas inaceitavelmente altas. As condições para a recupera-

3 Em seu Business Cycles, Schumpeter (1939) analisou a Grande Depressão dos anos 1930 a partir de três economias: Estados Unidos, Alemanha e Reino Unido. 
ção da demanda privada ainda não estão plenamente implementadas. Não podemos descansar até que a economia global esteja totalmente recuperada e as famílias trabalhadoras em todo o mundo possam encontrar empregos dignos.

Comprometemo-nos, nesse momento, a manter nossa resposta política forte até que seja assegurada uma recuperação duradoura. Agiremos para garantir que quando voltar a haver crescimento, haverá também empregos. Evitaremos qualquer eliminação prematura do estímulo.[...] (G-20 SUMMIT, 2009, grifos nossos)

Com a crise grega já exposta desde o fim do ano de 2009,o tom mudou na reunião de 2010 dos líderes do G-20. ${ }^{4}$ Apesar de as maiores economias permanecerem em recessão ou estagnação, os líderes do G-20 abriram espaço para uma mudança significativa: de políticas de estímulo fiscal para políticas de austeridade. ${ }^{5}$ As preocupações cresceram em relação aos problemas dos orçamentos públicos. Foi abandonada a promessa de que as políticas antidepressivas seriam mantidas até que uma recuperação duradora fosse alcançada. Foi também deixada de lado a promessa de que não haveria eliminação prematura dos estímulos. Os líderes afirmaram:

[...] os eventos recentes destacam a importância das finanças públicas sustentáveis e a necessidade de nossos países criarem planos críveis e adequadamente formatados que sejam favoráveis ao crescimento e para oferecer sustentabilidade fiscal, diferenciados e adaptados às circunstâncias nacionais. Países com sérios desafios precisam acelerar o ritmo de consolidação [fiscal]. (G-20 SUMMIT, 2010, grifos nossos)

E as posições dos líderes para ação dos países do G-20 se tornaram bastante explícitas na plataforma de recomendações daquela reunião de 2010. Eles estabeleceram que:

Finanças fiscais sólidas são essenciais para sustentar a recuperação, oferecer flexibilidade para responder a novos choques, garantir a capacidade de enfrentar os desa-

4 O periódico The Guardian (2015) fez uma timeline da crise grega e destacou: "19 de outubro de 2009Grécia admite buraco negro financeiro. O novo governo socialista de George Papandreou revela uma grande diferença nas contas da Grécia. Ele admite que o deficit será dobrado em relação à estimativa do governo anterior e baterá $12 \%$ do PIB. Os temores de que a Grécia possa entrar em default de suas dívidas cresce quando o primeiro-ministro diz que a economia está sob cuidado intensivo".

5 As maiores economias do mundo tinham taxas de desemprego bem elevadas em 2010; na zona do euro era de 10,1\%, nos Estados Unidos, de 9,6\%, na França, 8,9\% e na Alemanha, 7\% (THE WORLD BANK, 2018). 
fios do envelhecimento da população, e evitar deixar as gerações futuras com um legado de deficits e dívidas.

[...] as economias avançadas se comprometeram com planos fiscais de pelo menos reduzir pela metade os déficits até 2013 e estabilizar ou reduzir as razões da dívida pública com o PIB até 2016. [...] Aqueles [países] com sérios desafios fiscais precisam acelerar o ritmo de consolidação. (G-20 SUMMIT, 2010)

A partir de então, as maiores economias do planeta e suas parceiras em desenvolvimento foram empurradas de volta para a crise. E quando emergiu a crise europeia de 2011, algumas de suas economias foram jogadas em queda livre no abismo da depressão. No mundo, configurou-se uma nova depressão. ${ }^{6}$

A crise atual tem características semelhantes àquelas das depressões anteriores. Foi disparada fora do mercado de bens e serviços e se internacionalizou. A economia norte-americana teve uma deflação logo em seguida ao choque de 1929 (por três anos). A deflação também caracterizou a Depressão do século XIX. ${ }^{7}$ Nos anos recentes, os Estados Unidos tiveram uma queda de preços no ano de 2009 (-0,36\%) e uma queda forte da inflação em relação ao período anterior a 2007 para valores próximos de $1 \%$ ao ano. Por outro lado, algumas economias da Zona do Euro tiveram deflação, com destaque para Grécia e Espanha, que tiveram quatro anos de deflação em um período de nove anos, entre 2007 e 2016 . No mesmo período, o Japão teve deflação em dois anos (2009 e 2016) (THE WORLD BANK, 2018).

Não houve nos últimos anos uma corrida protecionista explícita como na década de 1930. Nessa época, havia a imposição de tarifas, variadas barreiras comerciais e os países recorriam a minidesvalorizações competitivas (STIGLITZ, 2010, p. 106). Houve retração do comércio internacional. Na depressão dos anos 1870, houve protecionismo (exceto por parte da principal economia da época, a Grã-Bretanha). Contudo, nessa crise, houve expansão do comércio internacional, ainda que com taxas inferiores

6 Comparando os acontecimentos dos anos 1930 e os últimos dez anos, Paul Krugman rotulou a situação econômica da década atual de depressão (ver, por exemplo, KRUGMAN, 2012). Eichengreen e O’Rourke (2010) afirmaram que, "[r] esumindo, globalmente estamos indo ou fazendo algo pior do que a Grande Depressão, seja a medida a produção industrial, a exportação ou a valorização de ações. Concentrar-se nos EUA faz com que se minimize esse fato alarmante. O rótulo 'Grande Recessão' pode se mostrar otimista demais. Este é um evento do tamanho da Depressão”. Blinder e Zandi (2010, p. 4) enfatizaram que: "[c]om uma clara deflação dos preços e dos salários em 2009-2011, este cenário escuro constitui uma depressão semelhante àquela da década de 1930”.

7 "[...] de 1873 a 1896, a baixa de preços de atacado foi de 32\% na Grã-Bretanha, de 40\% na Alemanha, de 43\% na França e de 45\% nos Estados Unidos” (COGIOLLA, 2009, p. 78). 
ao período pré-crise - além de um forte movimento de colonização dos países centrais em direção à Ásia e à África. ${ }^{8}$

Para além desses eventos mencionados que ocorreram nas duas grandes crises dos séculos XIX e XX (e que porventura ocorreram de forma semelhante ou não nos últimos anos), emergiu na depressão atual uma grande marca. Tal como nas depressões anteriores, houve queda acentuada do produto e elevação do desemprego e ambas as variáveis têm consumido um longo período para voltar aos patamares pré-crise. Essa é a marca explicativa da existência de uma depressão, no passado ou no presente. Existe sempre, em todos os eventos, uma insuficiência de demanda prolongada.

Considerando as principais economias, Estados Unidos, Japão e países da Zona do Euro, de acordo com a Tabela 1, foi observado que todas entraram em recessão nos anos de 2008 ou 2009, com quedas bastante acentuadas dos seus PIB e encontraram vales profundos. Fizeram vários episódios de crescimento e recessão no período que foi de 2007-2008 (pré-crise) ao ano de 2016. Aliás, essa é uma característica do que ocorre no interior das depressões: movimentos positivos e negativos do PIB, que são voláteis e de baixa magnitude.

Algumas das economias analisadas já recuperaram o PIB pré-crise e outras ainda permanecem em fase de crise do produto (ou seja, ainda registraram um PIB menor em 2017 que o produto pré-crise). Contudo, os anos de 2017-2018 parecem ter sido muito mais favoráveis para algumas economias que estiveram e estão mergulhadas na depressão. Os Estados Unidos são uma exceção entre os países selecionados. Têm recuperado suas taxas de crescimento e emprego ao longo do biênio 2017-2018.

A trajetória norte-americana é resultado da política fiscal adotada em 2008 (Economic Stimulus Act of 2008) e que se prolongou até 2010 - tal política estancou a queda livre do produto. A partir de então, a recuperação norte-americana é resultado principalmente da sua agressiva política monetária (quantitative easing) que teve início também em 2008 e que tem se prolongado - a despeito da redução de intensidade dos últimos anos. Após ter enfrentado duas recessões (em 2008 e 2009), a economia norteamericana entrou em rota de crescimento de taxas positivas que variam entre 1,5 e $3,0 \%$ anuais (THE WORLD BANK, 2018). O caso norte-americano de política monetária agressiva configura o movimento em que foi identificado que houve vazamento de moeda do sistema financeiro para a economia real (tal como explicado na teoria de Keynes).

Para ilustrar os fatos descritos foi configurada a Tabela 1. Um exemplo de leitura dessa tabela: a Itália entrou em depressão no ano de 2008 (coluna 1); o seu vale, que

8 Ver Coggiola (2009, p. 79-80 e p. 81-106). 
ocorreu no ano de 2013, representa um PIB 8,2\% menor em relação ao PIB pré-crise (coluna 2); em 2016, registrou um PIB 6,2\% menor do que o PIB pré-crise, que é o PIB real médio de 2007-2008 (coluna 3). Portanto registrou nove anos de crise do produto, dado que não recuperou em 2016 o PIB pré-crise (coluna 4). No período de 2008 a 2016, registrou quatro anos de recessão (coluna 5 ) e cinco anos de crescimento (coluna 6). ${ }^{9}$

\section{Tabela 1 - Países selecionados, variação do PIB e quantidade de anos de crescimento, em recessão e em crise, de 2007-2008 a 2016}

\begin{tabular}{|c|c|c|c|c|c|}
\hline $\begin{array}{l}\text { Países/ano da } 1^{\mathrm{a}} \\
\text { recessão }\end{array}$ & $\begin{array}{l}\text { Ano do vale/ } \\
\text { produto em } \\
\text { relação a } \\
2007-08\end{array}$ & $\begin{array}{c}\text { PIB de } 2016 \text { em } \\
\text { relação ao PIB } \\
\text { de 2007-08 }\end{array}$ & $\begin{array}{l}\text { Quantidade de } \\
\text { anos em crise do } \\
\text { produto }\end{array}$ & $\begin{array}{c}\text { Quantidade de } \\
\text { anos de recessão }\end{array}$ & $\begin{array}{l}\text { Quantidade de } \\
\text { anos de } \\
\text { crescimento }\end{array}$ \\
\hline $\begin{array}{l}\text { Itália } \\
(2008)\end{array}$ & $\begin{array}{c}2013 \\
-8,2 \%\end{array}$ & $-6,2 \%$ & 9 & 4 & 5 \\
\hline $\begin{array}{l}\text { Espanha } \\
(2009)\end{array}$ & $\begin{array}{c}2013 \\
-8,4 \%\end{array}$ & $-0,7$ & 8 & 5 & 3 \\
\hline $\begin{array}{l}\text { Grécia } \\
(2008)\end{array}$ & $\begin{array}{c}2013 \\
-26,4 \%\end{array}$ & $-26,3$ & 9 & 8 & 1 \\
\hline $\begin{array}{l}\text { Portugal } \\
(2009)\end{array}$ & $\begin{array}{c}2013 \\
-7,8 \%\end{array}$ & $-3,8$ & 8 & 4 & 4 \\
\hline $\begin{array}{l}\text { Zona do Euro* } \\
\text { (2009) }\end{array}$ & $\begin{array}{c}2009 \\
-4,6 \%\end{array}$ & $+3,1 \%$ & 7 & 3 & 4 \\
\hline $\begin{array}{l}\text { Japão } \\
(2008)\end{array}$ & $\begin{array}{c}2009 \\
-5,9 \%\end{array}$ & $+4,0 \%$ & 6 & 3 & 3 \\
\hline $\begin{array}{l}\text { Estados } \\
\text { Unidos } \\
(2008)\end{array}$ & $\begin{array}{c}2009 \\
-2,9 \%\end{array}$ & $+12,5 \%$ & 4 & 2 & 2 \\
\hline
\end{tabular}

Notas: (*) A Zona do Euro superou no ano de 2015 o PIB médio dos anos 2007-2008. (**) O Japão superou no ano de 2013 o PIB médio dos anos 2007-2008. (***) Os Estados Unidos superaram no ano de 2011 o PIB dos anos 2007-2008.

Fonte: Elaboração própria com base nos dados do The World Bank (2018).

Cabe ainda analisar o desemprego nessas economias. Afinal, o que caracterizaria a superação completa do estado de depressão seria a recuperação do PIB original pré-crise e, também, a taxa de desemprego pré-crise. Dada a gravidade da Grande Depressão,

9 O leitor pode estranhar que fizemos referências às principais economias do planeta, exceto à economia chinesa. Isso ocorreu porque só foram consideradas economias que são puramente de mercado. A administração da economia chinesa é reconhecidamente estatal, centralizada e planejada, o que tem deixado esse país com autonomia de administração do seu poderoso mercado doméstico e com capacidade de manejo do potencial de utilização do seu mercado externo. O modelo chinês, até o momento, parece ter sido eficaz para manter relações externas sem ser contaminado por elas. A China tinha uma estratégia de crescimento anual de $10 \%$ (ou mais) no período anterior a 2010; posteriormente readequou essa estratégia para algo em torno de $7 \%$ ao ano. E assim o fez, ultrapassando com habilidade e destreza as crises que enfrentam as economias capitalistas de mercado. 
Keynes também destacou a necessidade de recuperar essas duas variáveis e que a questão básica era: "como poderíamos nos levantar do estado de crise aguda em que havíamos caído, elevando o volume de produção e [trazendo] o desemprego de volta a um quadro normal” (KEYNES, 1982, p. 39).

Uma economia estará recuperada de uma depressão quando estabelecer trajetórias benignas para ambas as variáveis, isto é, crescimento econômico que mantenha pelo menos a taxa de desemprego do período pré-crise. Assim foi com a economia norte-americana na Grande Depressão do século passado. Embora a economia dos Estados Unidos tenha recuperado o PIB do ano de 1929 em 1936, em 1938 voltou a ter uma recessão. Posteriormente, recuperou o PIB de forma acelerada com o superaquecimento econômico proporcionado pela Segunda Guerra Mundial. Contudo, somente em 1943 obteve uma taxa de desemprego menor que aquela de 1929, ou seja, 14 anos depois da quebra da Bolsa de Valores norte-americana. Em 1929, havia 1,55 milhão de desempregados; em 1933, eram 12,8 milhões; mas, em 1943, esse número baixou para 1,07 milhão (BLS, 1948). ${ }^{10}$

O Gráfico 1 mostra a evolução, nos Estados Unidos, do PIB e da taxa de desemprego entre 1929 e 1947, com destaque para o ano de 1936, em que houve a recuperação do nível do PIB pré-crise, e para o ano de 1943, em que houve a recuperação da taxa de desemprego para um patamar menor do que aquele do ano pré-crise.

A lição norte-americana dos anos 1930 é a seguinte: primeiro vem a recuperação do produto e posteriormente vem a recuperação do emprego; somente quando ambas as variáveis estão quantitativamente recompostas é que a economia poderá indicar uma trajetória consistente de crescimento econômico suficiente para manter pelo menos uma taxa de desemprego igual àquela do período anterior à depressão.

Dentre as economias selecionadas para observação, ou seja, Estados Unidos, Japão e economias da Zona do Euro, somente o país asiático obteve em 2016 uma taxa de desemprego menor que a taxa encontrada em 2007. Em 2016, os Estados Unidos obtiveram ainda uma taxa ligeiramente maior que a taxa do ano pré-crise. A Zona do Euro e alguns de seus membros, tais como Portugal, Grécia, Itália e Espanha, ainda conviveram, em 2016, com taxas muito superiores àquelas do período pré-crise (tal como

${ }^{10} \mathrm{Na}$ depressão norte-americana iniciada em 1873, a taxa de desemprego era de 3,99\%. Atingiu o seu pico em 1878 , com $8,25 \%$. Somente retornou ao patamar pré-crise em 1882, com 3,29\%. Depois voltou a crescer lentamente, mas se recuperou novamente em 1890, com 3,97\%. E novamente voltou a crescer durante a década de 1990 (VERNON, 1994). Nas palavras de Dobb (1983, p.214): “[...] Grande Depressão, iniciada em 1873, [foi] interrompida por surtos de recuperação em 1880 e 1888, e continuada até meados dos anos 1990 [...]”. Por isso é possível encontrar na literatura de forma bastante ampla a denominação de Longa Depressão para esse evento do XIX. 
pode ser observado na Tabela 2). Portanto não se pode observar a recuperação da depressão em termos de produto e emprego, simultaneamente. Mesmo o Japão, que apresentou os melhores resultados em termos das duas variáveis, teve um baixíssimo crescimento em 2015 e 2016 e teve uma deflação nesse último ano. ${ }^{11}$ A economia mundial, representada pelos países selecionados, apesar de estar em uma conjuntura muito mais favorável (no biênio 2017-2018), ainda possui um arranjo muito frágil e está bastante vulnerável a choques que em outros tempos seriam facilmente absorvidos. ${ }^{12}$

\section{Gráfico 1 - Estados Unidos: PIB, em bilhões de US\$ de 2009, e taxa de desemprego, em \%, 1929-1947}

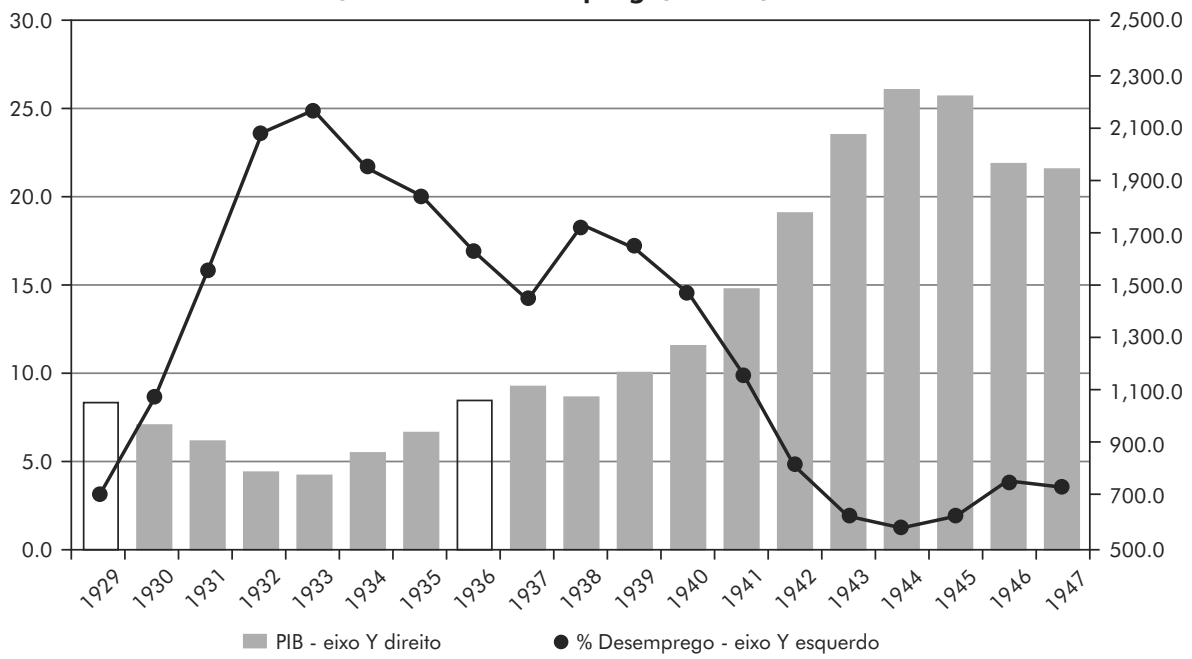

Fonte: BLS (1948) e BEA (2018).

${ }^{11}$ As economias de França, Alemanha e Reino Unido (esta última fora da Zona do Euro) tiveram forte desaceleração em 2008 e recessão acentuada no ano de 2009 (respectivamente, $-2,9 \%,-5,6 \%$ e $-4,2 \%$ ). A taxa de desemprego cresceu de forma aguda a partir desse ano para os franceses e britânicos. A França tinha uma taxa de desemprego pré-crise de 7,1\% (2008); em 2016 ainda era de 10,1\%. O Reino Unido tinha uma taxa pré-crise de 5,6\% (2008); em 2015, recuperou o patamar pré-crise de desemprego. A Alemanha foi pouco afetada. Esse país teve um pequeno aumento do desemprego durante o ano de 2009 (de 7,5 para 7,7\%); em 2016 obteve 4,1\%. No período pós-recessão de 2009, esses três países têm apresentado modestas taxas de crescimento econômico, e indicam resultados mais favoráveis para o biênio 2017-2018.

12 Na seção 4 (tópicos A e B) será argumentado que economias em depressão estão fora do estado de normalidade original e isso corresponderia a mais incerteza, mais fragilidade para absorção de choques e algum grau de paralisia dos agentes econômicos. 
Tabela 2 - Países selecionados, taxa de desemprego em 2007/2016 e maior taxa do período

\begin{tabular}{lccc}
\hline & \multicolumn{3}{c}{ Taxa de Desemprego entre 2007 e 2016 (em \%) } \\
\cline { 2 - 3 } Países & $\mathbf{2 0 0 7}$ & $\begin{array}{c}\text { Maior taxa de desemprego do período } \\
\mathbf{2 0 0 7 - 2 0 1 6}(\mathbf{a n o})\end{array}$ & $\mathbf{2 0 1 6}$ \\
\hline Itália & 6,1 & $12,7(2014)$ & 11,7 \\
Espanha & 8,2 & $26,1(2013)$ & 19,6 \\
Grécia & 8,4 & $27,5(2013)$ & 23,5 \\
Portugal & 8 & $16,2(2013)$ & 11,1 \\
Zona do Euro & 7,4 & $11,9(2013)$ & 10 \\
Japão & 3,8 & $5,1(2009$ e 2010) & 3,1 \\
Estados Unidos & 4,6 & $9,6(2010)$ & 4,9 \\
\hline
\end{tabular}

Fonte: The World Bank (2018).

\section{ARGUMENTOS QUANTITATIVOS: PROFUNDIDADE E DATAÇÃO DA DEPRESSÃO BRASILEIRA}

A economia brasileira está dentro da depressão mundial. Houve uma queda acentuada do produto desde meados de 2014 até o final de 2016 . Entre o $1^{\circ}$ trimestre de 2014 e o $4^{\circ}$ trimestre de 2016 a queda foi de $8,3 \%$ (IBGE/SCNT, 2018). A profundidade da queda é assemelhada àquelas dos países mais atingidos da Zona do Euro, tais como Portugal, Itália e Espanha.

Considerando a trajetória do PIB até o ano de 2017, o vale da depressão brasileira foi no $4^{\circ}$ trimestre de 2016. Contudo, no meio de um processo de longa duração, com incertezas e vulnerabilidades, não se pode afirmar com segurança que a trajetória futura do PIB será de crescimento, ainda que com taxas baixas e voláteis. Em um quadro depressivo, inclusive, novas recessões poderão vir a ocorrer. O Brasil passou recentemente por essa alternância ao longo do ano de 2014, tal como pode ser observado no Gráfico 2.

O Brasil entrou em crise no $2^{\circ}$ trimestre de 2014, com crescimento do PIB naquele ano de apenas 0,5\%. Mergulhou na crise em 2015 e 2016, com recessões de $-3,8 \%$ e $-3,6 \%$, respectivamente. E apresentou taxa de crescimento pífio em 2017, somente $1 \%$ (IBGE/SCNT, 2018). Como pode ser observado no Gráfico 2, o Brasil já está em crise do produto por mais de quatro anos. Dentre os países analisados anteriormente (ver Tabelas 1 e 2), somente os Estados Unidos tiveram uma crise de produto mais curta, mas a queda norte-americana foi somente de 2,9\% do PIB. Portanto, é provável que o Brasil, tal como os países europeus mais atingidos, ainda demore alguns anos para recuperar o PIB do período pré-crise (o PIB do $1^{\circ}$ trimestre de 2014). 


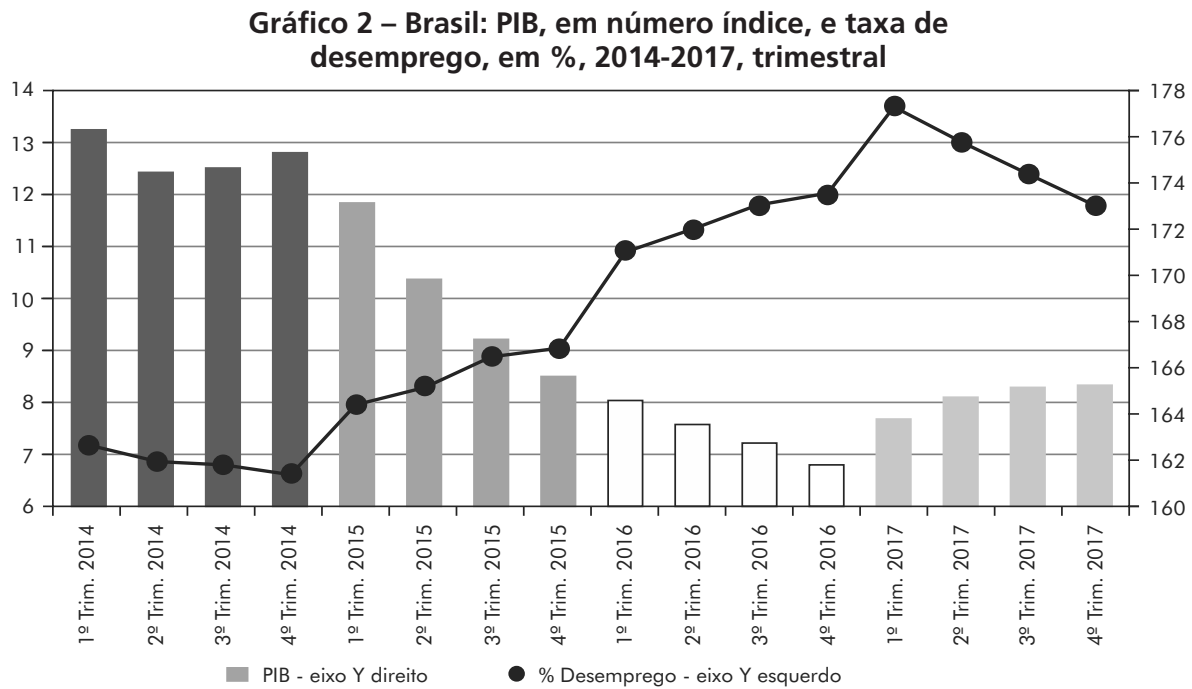

Fonte: Elaboração própria com base em dados do PIB extraídos de IBGE/SCNT (2018) e em dados de desemprego extraídos de IBGE/PNAD Contínua (2018).

Recuperar o produto não será o suficiente para a superação da depressão brasileira. Vale lembrar que a economia dos Estados Unidos, no século passado, somente superou a depressão quando recuperou também a taxa de desemprego pré-crise. A taxa de desemprego no Brasil está muito alta durante a crise. No trimestre anterior à crise era de $7,2 \%$. Alcançou 13,7\% no $1^{\circ}$ trimestre de 2017. E no $1^{\circ}$ trimestre de 2018 ainda se encontra em 13,1\% - uma taxa muito distante do nível original (ver Gráfico 2).

Além do nível e variações do produto e da taxa de desemprego, é necessário acrescentar alguns argumentos quantitativos à análise do caso brasileiro para caracterizar de forma mais minuciosa o estado de depressão econômica existente. A seguir são apreciadas as relações entre o número de trabalhadores com carteira assinada no setor privado e a taxa de desemprego e entre o nível de capacidade ociosa e o investimento. E, ainda, é analisada a taxa de variação do estoque de capital da economia.

\section{A) Número de trabalhadores com carteira assinada}

O Brasil teve uma característica peculiar de países em desenvolvimento que possuem amplos mercados informais de trabalho: o grau de informalidade no mercado de trabalho variava de acordo com o crescimento econômico, isto é, uma trajetória contínua de crescimento implicava menos informalidade. ${ }^{13}$ Contudo, existiram movimentos importantes na

13 É provável que tais parâmetros comportamentais tenham se modificado a partir do $4^{\circ}$ trimestre de 2017 em função da profunda reforma trabalhista que entrou em vigor em novembro do referido período. 
composição (formal versus informal) do mercado de trabalho que valem ser destacados em cenários de possíveis inflexões (acelerações ou desacelerações do produto).

Diante de uma desaceleração econômica, os empresários buscavam reduzir custos devido à queda dos lucros. Primeiramente, dentre as suas ações estava a troca de ofertas de vagas formais por informais. Posteriormente, se confirmada a queda, ocorreriam as demissões. Por outro lado, se eles ainda não confiavam numa retomada do crescimento, o primeiro passo também poderia ser a contratação de trabalho informal. E, se fosse o caso, depois viriam as contratações formalizadas. Portanto, a taxa de desemprego poderia não aumentar nos primeiros momentos de uma desaceleração ou recessão (havendo apenas o crescimento da informalidade); mas poderia cair logo em seguida ao crescimento devido à contratação de desempregados que passariam para a condição de trabalhadores empregados, mas sem carteira.

A síntese é que a trajetória do grau de formalização, que no caso brasileiro pode ser representada pela trajetória da quantidade de trabalhadores com carteira assinada no setor privado, é uma variável que pode acompanhar de forma mais próxima (do que a taxa de desemprego) as variações iniciais do produto quando existem desacelerações ou recessões. Suas variações, em cenários de desaceleração, são indicadoras antecedentes do que ocorrerá com a taxa de desemprego.

No ano de 2014, quando a crise teve início, a taxa de desemprego não foi negativamente afetada. Porém o número de trabalhadores com carteira assinada começou a decair (a partir do $3^{\circ}$ trimestre) em ritmo de queda livre. Caiu, trimestre após trimestre, de 36,9 milhões de trabalhadores no $2^{\circ}$ trimestre de 2014 para 33,3 milhões no $3^{\circ}$ trimestre de 2017, tal como pode ser visto no Gráfico $3 .^{14}$

Em 2017 houve crescimento do PIB. Foi um crescimento baixo e que não revelou confiança empresarial na sua elevação e continuidade, já que contrataram trabalhadores, mas não assinaram as suas carteiras. Mais grave ainda, apesar da redução da taxa de desemprego de $13,7 \%$ para $12,4 \%$, houve redução da quantidade de trabalhadores

Adiciona-se a essa mudança a nova Lei da Terceirização, também promulgada em 2017, que permite a terceirização ilimitada e irrestrita, ou seja, em todas as atividades da empresa. Em cenário anterior a tais mudanças de regras, segundo relatório da ILO (2014), o grau de informalidade na América Latina (13 países) em 2012 era de 47,7\%. Essa taxa, embora elevada, já refletiu, segundo o relatório, o crescimento econômico da primeira década associado às políticas de promoção da formalização da força de trabalho. Por exemplo, a redução da informalidade no Brasil foi de 13,9 pontos percentuais; na Argentina, de 14,5; no Peru, de 6,6; e no Uruguai, de 15,1.

${ }^{14}$ No $4^{\text {o }}$ trimestre de 2017, o número de trabalhadores com carteira assinada se manteve estável em relação ao trimestre anterior. No $1^{\circ}$ trimestre de 2018 , caiu ligeiramente para 32,1 milhões. Esses trimestres não foram incluídos no Gráfico 3 porque possivelmente devem ser analisados com novos parâmetros comportamentais, tal como explicado na nota anterior. 
com carteira de 33,4 milhões para 33,3 milhões entre o $1^{\circ}$ e $3^{\circ}$ trimestres daquele ano, tal como pode ser observado no Gráfico 3.

\section{Gráfico 3 - Brasil: número de trabalhadores com carteira no setor privado, 2012-2017, trimestral, em 1 mil}

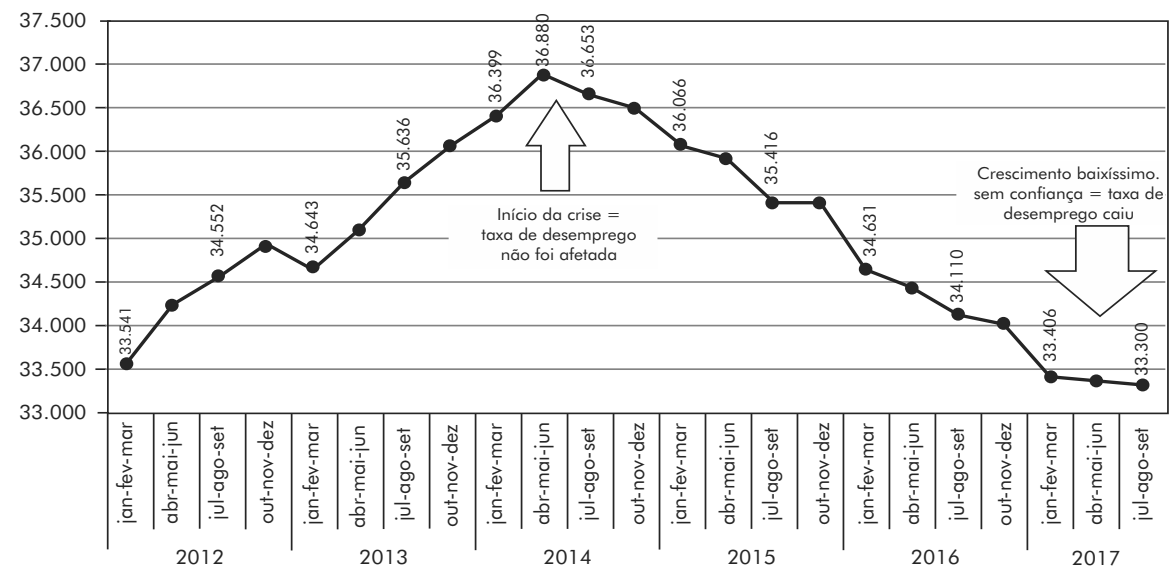

Fonte: IBGE/PNAD Contínua (2018).

A análise dessa variável indicou que a crise econômica depressiva teve início em 2014 e que os empresários não revelaram confiança na continuidade e aceleração do crescimento de 2017.

\section{B) Nível da capacidade ociosa e investimento}

Há uma insuficiência de demanda (que provavelmente deve ser longa) que reduziu a ocupação da capacidade instalada existente e, mais ainda, diminuiu a realização de investimentos. Essas duas variáveis (investimentos e capacidade ociosa) devem ser analisadas em conjunto. A ampliação da capacidade ociosa tem como correspondente o desemprego. Tal como descreveu Kalecki:

O desemprego em massa parece ser o mais evidente sintoma da depressão econômica. [...]. Durante a depressão econômica o equipamento de capital existente é utilizado em pequeno grau: o equipamento ocioso é a contrapartida da força de trabalho desempregada. (KALECKI, 1980, p. 60)

Como pode ser observado no Gráfico 4, já ao final de 2013 teve início um longo período de queda da utilização da capacidade instalada. Entre o início da crise e os últimos dados apresentados no gráfico, o declínio é de mais de cinco pontos percentuais. Foram três anos de quedas sucessivas (2014, 2015 e 2016) e crescimento em 2017 e janeiro de 2018 de menos de um ponto percentual. 
Gráfico 4 - Brasil: utilização da capacidade instalada da indústria, em \%, mensal, dessazonalizado, 01/2004 - 01/2018, em média móvel 12 meses

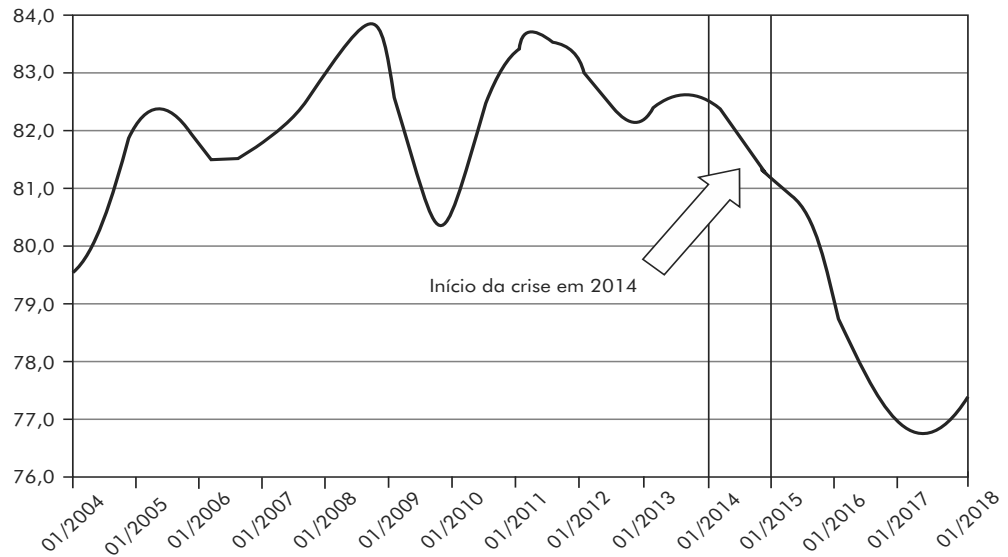

Gráfico 5 - Brasil: Investimento (FBCF), em número índice trimestral, dessazonalizado, 2004-2017

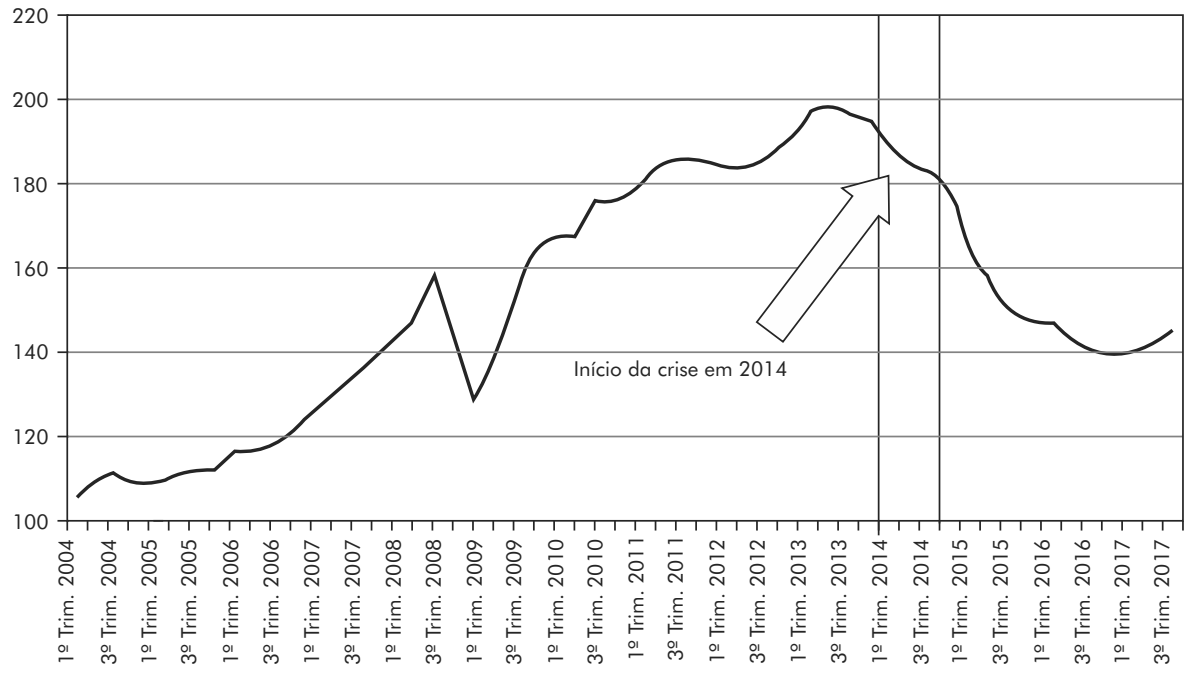

Fonte: IBGE/SCNT (2018).

Como resultado da baixa utilização da capacidade instalada, houve uma redução aguda do investimento (Formação Bruta de Capital Fixo). A queda foi de 25,3\% entre o $1^{\circ}$ trimestre de 2014 e o último trimestre de 2017, apesar do ligeiro crescimento ocorrido nesse último ano (ver Gráfico 5). Cabe observar, nas palavras de Keynes, a semelhança com a Grande Depressão: 
O colapso do nível de investimento em 1930 era não explicado. Naturalmente existiram todo tipo de razões para esse colapso, mas o principal ponto a ser observado é que o colapso do investimento foi a causa da depressão. (KEYNES, 1981, p. 479-480)

A análise dessas duas variáveis indicou que a crise econômica depressiva apresentou seus primeiros sinais ao final de 2013, mas se consolidou enquanto trajetória durante o ano de 2014.

\section{C) Acumulação de capital}

Mais grave e característico de uma depressão foi que a queda do investimento, descontada a depreciação, interrompeu a acumulação líquida de capital da economia brasileira. Esse quadro configura, para Hicks, uma depressão:

O traço característico de uma depressão econômica não é a desacumulação de capital físico [...] é a mera interrupção da acumulação; ela é suficiente, por si só, para produzir os fenômenos típicos da depressão [...] (HICKS, 1987, p. 239)

Segundo Hicks (1987, p. 239), o congelamento do estoque de capital sintetizaria a existência da depressão por provocar o adiamento de gastos por parte dos agentes e o deslocamento da demanda de bens e fatores (capital e trabalho) para moeda e títulos.

Como pode ser observado no Gráfico 6, a taxa trimestral de crescimento (trimestre contra trimestre anterior) do estoque de capital, que era 1\% no período (de 2011 a 2013) anterior à crise, começou a declinar ao final de 2013. Alcançou valor muito baixo $(0,25 \%)$ no último dado disponível, que foi o $2^{\circ}$ trimestre de 2017 . A taxa de crescimento, trimestre após trimestre, é decrescente e inferior a $1 \%$ desde o $1^{\circ}$ trimestre de 2014. Os valores dos últimos seis trimestres aproximaram a taxa de zero, o que significa a "mera interrupção da acumulação" enfatizada por Hicks.

O nível de capacidade ociosa começou a aumentar na passagem de 2013 para 2014 (ver Gráfico 4). O volume de investimentos começou a decrescer desde o $4^{\circ}$ trimestre de 2013 (ver Gráfico 5). Nessa mesma passagem (de 2013 para 2014), teve início a queda das taxas de crescimento do estoque de capital em direção a zero (ver Gráfico 6). O evento revelador do comportamento desse conjunto de variáveis (mais subterrâneas) foi a queda do produto do $2^{\circ}$ trimestre de 2014. Tal fraqueza da economia, que era abrangente, foi confirmada pela queda a partir do $3^{\circ}$ trimestre de 2014 do número de trabalhadores com carteira assinada no setor privado (ver Gráfico 3). Nesse sentido, pode-se datar o início da depressão brasileira a partir do $2^{\circ}$ trimestre de $2014 .{ }^{15}$

15 Orair, Siqueira e Gobetti (2016) construíram uma variável para datar os ciclos econômicos. Quando tal variável ultrapassa 0,8 numa escala que vai de 0 a 1 , atinge a probabilidade de a economia estar em recessão. Em seu trabalho, os autores concluíram que a economia brasileira entrou em recessão logo no início de 2014, o que corrobora nossa datação do início da depressão brasileira. 
Gráfico 6 - Brasil: taxa de crescimento do estoque de capital em relação ao trimestre anterior, em \%, do $1^{\circ}$ trimestre de 2011 ao $2^{\circ}$ trimestre de 2017

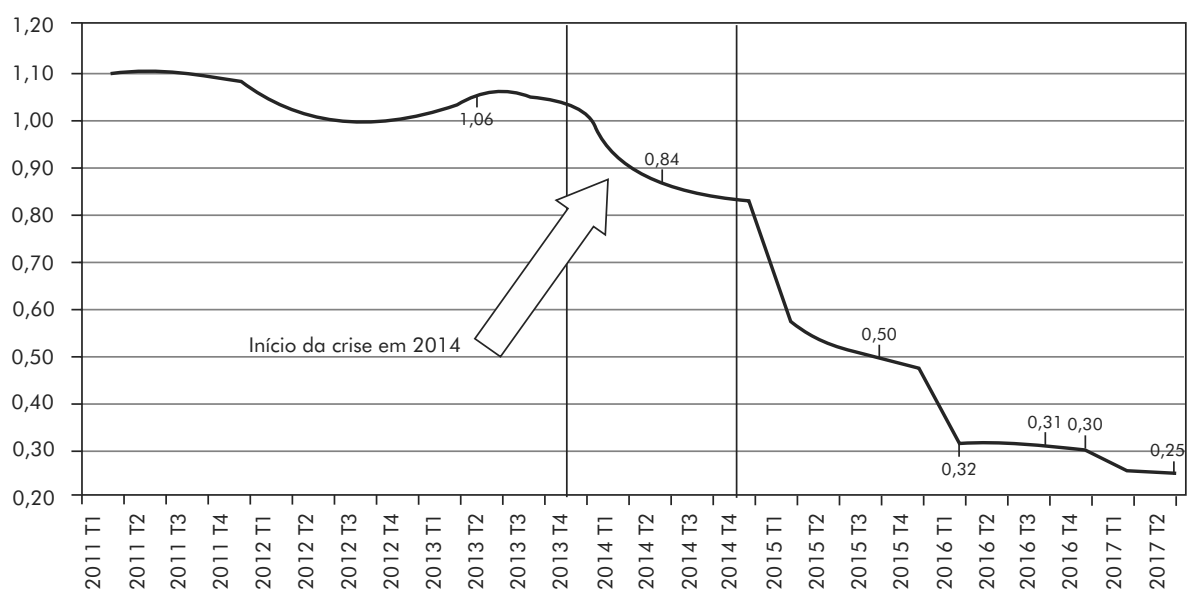

Fonte: Elaboração própria com base em dados do IPEA (2017).

\section{ADICIONANDO ARGUMENTOS TEÓRICOS E QUALITATIVOS: O MUNDO E O BRASIL NA DEPRESSÃO}

Não existe uma teoria estabelecida da depressão. O que existe é uma tentativa de se conhecer e teorizar sobre a economia da depressão. O número de eventos de depressões é bastante reduzido. O que se faz atualmente é mostrar semelhanças e diferenças entre os eventos passados e o que transcorre nessa segunda década do século XXI. E, a partir daí, busca-se estabelecer abordagens teóricas sobre a caracterização de uma depressão. ${ }^{16}$ Existem alguns pontos de convergência: (i) a depressão é um evento internacionalizado e atinge as maiores economias do planeta; (ii) é um evento de longa duração; (iii) nem toda recessão leva a economia para a depressão; e (iv) as recessões são consideradas normais; as depressões, não. O assunto (i) já foi tratado anteriormente, os demais são tratados a seguir.

\section{A) A depressão é uma trajetória de longa duração}

A experiência dos anos 1870 e 1930 e a recente experiência que teve início em 2008 indicam que a depressão é um estado econômico de longa duração. Um critério para avaliar a saída de uma depressão seria quando o país recupera o produto e a taxa de

${ }^{16}$ Ver, por exemplo, Cardim de Carvalho (2016). 
desemprego com valores do período pré-crise (critério 1). ${ }^{17}$ Por esse critério, os Estados Unidos somente teriam superado a Grande Depressão 14 anos após o seu início em 1929 (ver Gráfico 1). Seguindo o mesmo critério, nos dias de hoje, pode-se dizer que são poucas as economias relevantes que realizaram, em 2016, a recuperação do produto e da taxa de desemprego do período pré-crise (os anos de 2007 e 2008).

Um critério mais rigoroso, que além de analisar as duas variáveis (produto e taxa de desemprego) leve em consideração também a recuperação da tendência de crescimento do período de normalidade (pré-crise), também pode ser utilizado (critério 2). Seguindo esse critério, pode-se inferir que nenhuma economia selecionada (Estados Unidos, Japão e Zona do Euro) recuperou a sua tendência de crescimento do período anterior à crise.

Um estado de depressão nos termos que é estabelecido na nossa análise utiliza como referência o esquema keleckiano de 1954 (KALECKI, 1983, capítulos 11 ao 15). No seu esquema, os ciclos eram regulares, as forças motrizes eram internas e os movimentos cíclicos não afetavam a linha de tendência de crescimento. Aqui os ciclos têm amplitudes diversas, existem também forças externas (que são as decisões de investimento baseadas em expectativas e as políticas de gastos públicos) e a amplitude de uma recuperação ou de uma recessão pode tirar a economia de sua trajetória. Portanto, existe correlação e causalidade entre os movimentos cíclicos e a trajetória de crescimento de longo prazo. ${ }^{18}$

Essa forma de analisar o problema pode ser observada no esquema apresentado na Figura 1. Há inicialmente um ciclo de normalidade. Posteriormente, a economia sofre um choque negativo que provoca uma profunda recessão (com elevação da taxa de desemprego). A normalidade é rompida e a economia sai da sua tendência de crescimento T para mergulhar na "escuridão" da depressão, um estado de anormalidade e de profundas incertezas. Para Kalecki, a depressão era uma fase do ciclo e não uma quebra da linha de tendência.

17 Existe um consenso de que a economia americana somente superou a Grande Depressão unicamente nos anos 1940, quando já tinha recuperado o produto original pré-crise (o que aconteceu em 1936) e uma taxa de desemprego semelhante àquela que tinha em 1929 (o que somente aconteceu em 1943). Portanto, ambas as variáveis, recuperação do tamanho do produto e da taxa de desemprego, podem ser consideradas como sintomas para avaliação da superação de estados de depressão. E foi somente em 1949 que os Estados Unidos recuperaram o nível de produção de automóveis que tinham em 1929 (COGGIOLA, 2009, p. 134).

18 A visão aqui adotada é expressa em algum sentido, por exemplo, em Fatás (2002, p. 214): “[...] os ciclos de negócios não podem ser considerados desvios temporários de uma tendência. [...] O fato de existir uma forte correlação positiva entre a persistência de flutuações de curto prazo e as taxas de crescimento de longo prazo contradiz os modelos de ciclo de negócios baseados em pequenos desvios de uma solução de estado estacionário em um modelo de crescimento tipo Solow". 
Figura 1 - Esquema ciclo-tendência-depressão em uma economia capitalista

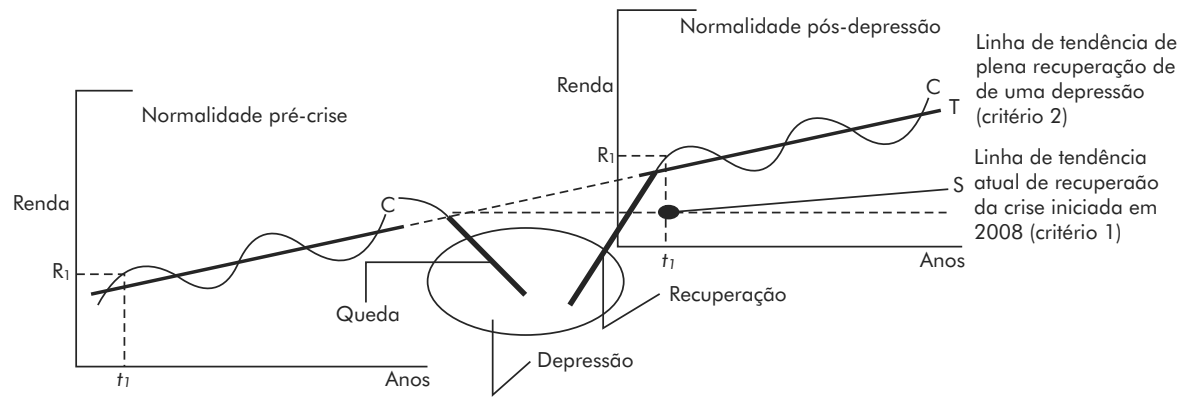

Fonte: Elaboração própria.

Seguindo a leitura do esquema, a economia poderá ser tirada da depressão se sofrer um choque positivo que a levará para uma fase de recuperação com posterior expansão. Se a economia voltar a transitar em torno da linha T, terá recuperado o tamanho do produto original e a sua tendência, ou seja, sua taxa média de crescimento será igual àquela que possuía antes da depressão - essa recuperação de dinâmica terá repercussões positivas sobre a redução da taxa de desemprego.

Recentemente as economias mais relevantes que apresentaram sinais de recuperação da crise iniciada em 2008 não voltaram para a linha T, embora tenham recuperado o tamanho do produto original. Estão em uma tendência assemelhada à linha $S$, isto é, suas taxas de crescimento são bem inferiores àquelas que possuíam no período pré-crise e suas taxas de desemprego (para boa parte dos países) continuam superiores àquelas dos anos 2007-2008.

Ainda que seja pelo critério 1, a economia brasileira está longe de ingressar em um estado normal de crescimento pós-crise: o tamanho do seu produto e sua taxa de desemprego estão muito distantes dos valores originais dos anos de 2013-2014 (tal como pode ser observado no Gráfico 2). Há mais de quatro anos o Brasil está em crise. Nesse período, teve uma forte desaceleração em 2014, duas agudas recessões em 2015 e 2016 e um pífio crescimento em 2017 e 2018. O Brasil continua mergulhado na depressão.

Cabe ser destacado que, após uma depressão, se uma economia não voltar para sua tendência de crescimento original (pré-crise), carregará para sempre uma perda de produto. Embora uma economia possa estar crescendo em torno da linha S, em quaisquer dos seus pontos sempre terá um produto menor do aquele que teria alcançado se não tivesse enfrentado a depressão, ou seja, se tivesse se mantido na tendência T.

A partir do momento que a economia mergulha em direção à depressão, governos podem fazer políticas econômicas para estancar a queda. Foi isso que foi feito, em 
2009, na maioria dos países, inclusive no Brasil. ${ }^{19}$ Essa reação para promover o estancamento da queda foi sugerida pela reunião de líderes do G-20 de abril e setembro daquele ano. Entretanto, como já visto, aquelas políticas foram desativadas a partir da reunião seguinte do G-20, em 2010. Assim, tais políticas reativas não se transformaram em políticas de recuperação em direção a uma nova normalidade.

Políticas econômicas do tipo keynesiana agem diretamente sobre o emprego e o produto (política de obras públicas, por exemplo) ou tentam estimular ações e reações privadas (as políticas monetárias de redução de juros e aumento da oferta de crédito, por exemplo). Contudo, dentro de estados de depressão, ações e reações precisam de tempo para ocorrer porque os agentes econômicos estão dentro de uma situação desconhecida e muito degradada economicamente (queda dos lucros, redução da capacidade de consumo etc). Fora de uma situação de normalidade, as decisões precisam de mais tempo para serem tomadas por parte dos agentes econômicos e, além disso, tendem a ser mais tímidas em suas magnitudes já que eles desconhecem quais são parâmetros que estão vigorando (se é que é possível reconhecê-los, já que podem estar mudando de forma contínua). Afinal, não existe a normalidade da depressão, tal como será argumentado na próxima seção. ${ }^{20}$

Mais demorada será a saída do estado de depressão se não houver qualquer política econômica de estancamento da queda e, posterior, política de recuperação. Portanto, mais profunda será a queda e mais demorada será a saída se for promovido um laissez-faire ao estilo do início dos anos $1930 .{ }^{21} \mathrm{Ou}$, ainda se as políticas econômicas adotadas e as reformas institucionais desenhadas, supostamente para estimular a recuperação, não contribuírem para uma arrancada em direção a uma nova normalidade de crescimento - em outras palavras, se tais arranjos contribuírem para conformar um

19 Para impedir um mergulho econômico em queda livre no ano de 2009, o governo brasileiro adotou inúmeras medidas específicas. Do ponto de vista das políticas monetária e fiscal, tomou as seguintes medidas: reduziu a taxa de juros básica da economia em cinco pontos percentuais e aumentou os investimentos (das três esferas) e das estatais federais de 3,7\% do PIB (em 2008) para 4,2\% (em 2009). A recessão brasileira foi de apenas 0,1\% (BCB, 2018; IBGE/SCNT, 2018).

${ }^{20}$ É exatamente pelo reconhecimento de que existe uma paralisia dos agentes econômicos que Keynes confiou na política de gastos públicos como instrumento de saída da depressão, já que tal política age diretamente sobre o desemprego. E não recomendava o uso exclusivo de políticas monetárias (redução dos juros) que dependem de reações e ações dos agentes privados (ver, por exemplo, capítulos 10 e 22 de KEYNES, 1973).

${ }^{21}$ Segundo descrição de Stiglitz, durante a Grande Depressão, "quando a economia mergulhou na recessão e depois na depressão, muitos deram um conselho simples: não fazer nada” (2010, p. 342). Em oposição, para Keynes, "Em condições de laissez-faire, evitar grandes flutuações no emprego pode, portanto, ser impossível sem uma mudança de longo alcance na psicologia dos mercados de investimento, tal mudança não há razão para ser esperada. Eu concluo que as encomendas correntes do volume de investimentos não podem seguramente ser deixadas nas mãos privadas" (KEYNES, 1973, p. 320). 
estado paralisante dentro da depressão. O caso do Brasil se assemelha a essa última possibilidade, tal como, por exemplo, Grécia, Itália ou Espanha. A descrição das políticas e reformas adotadas pelo Brasil está desenvolvida na próxima seção.

\section{B) Que tipo de recessão provoca o mergulho na depressão}

Os movimentos cíclicos que interferem na tendência de crescimento são de tipo específico. Segundo Schumpeter (1939), quando acontecem agudas recessões, tal como no início dos anos 1930 nos Estados Unidos (mas também na Alemanha e Inglaterra), em que as quedas são retroalimentadas e erráticas do emprego/produto/crédito por dois ou três anos estaria caracterizada a existência de uma espiral viciosa (vicious spiral). Para ele, referindo-se aos anos de 1931 e 1932: “[...] [a] Espiral Viciosa [foi] a característica mais marcante daqueles anos [...]" (SCHUMPETER, 1939, p. 925).

A existência dessa espiral, segundo Schumpeter (1939), seria o suficiente para caracterizar uma depressão. A existência desse elemento seria a demonstração de que houve uma transformação qualitativa: de uma recessão, que é algo normal, para uma depressão, que é anormal. Vejamos as palavras de Schumpeter referindo-se à espiral viciosa, que foi considerada por ele como o novo elemento do cenário que analisava:

[...] sabemos que o processo assim designado é, em maior ou menor grau, uma característica de qualquer depressão. É, de fato, o grande responsável por transformar a "liquidação normal" da recessão na "liquidação anormal" da depressão. (SCHUMPETER, 1939, p. 925) 22

O termo normal é aqui utilizado por Schumpeter nas mesmas bases que Keynes utilizou, ou seja, como Alfred Marshall havia definido:

o emprego do termo normal implica a predominância de certas tendências, que se afiguram ser mais ou menos firmes e persistentes na sua atuação, sobre outras relativamente excepcionais e intermitentes. A doença é uma condição normal do homem. Mas uma longa existência transcorrida sem qualquer doença é anormal. [...] Em todos os casos, os resultados normais são os que se podem esperar... (MARSHALL, 1985, p. 47) ${ }^{23}$

${ }^{22}$ Para Schumpeter (1939), o termo liquidação significava uma revisão descendente de níveis de variáveis e operações, ou seja, um rebaixamento contínuo do nível de variáveis, tais como: produto, emprego e crédito. Quando era uma situação anormal, tal rebaixamento acontecia de forma profunda e errática.

23 Apresentação mais detalhada sobre o conceito de normalidade definido por Marshall pode ser encontrada em Sicsú (1999). Detalhes sobre a herança metodológica que Alfred Marshall deixou para Keynes e os pós-keynesianos foram apresentados e discutidos em Cardim de Carvalho (1992, capítulo 2). 
Dessa forma, a partir das contribuições de Schumpeter e Marshall, pode-se dizer que uma recessão, embora não desejada devido à liquidação que ocorre, é considerada normal. Segundo Marshall, os agentes econômicos saberiam como reagir em condições de normalidade, ainda que seja em condições não desejadas. Em uma recessão normal, os eventos, em média, são repetidos, mostram-se sistemáticos e têm frequência aproximadamente conhecida. Mais: tendências comportamentais, algumas transformações conjunturais e mudanças de níveis de determinadas variáveis podem ser esperadas com algum grau de segurança.

As recessões (isentas de uma espiral viciosa) são comuns, ou seja, têm se repetido ao longo do tempo, o que tem possibilitado o conhecimento e o aprendizado sobre esse tipo de fase do ciclo. O National Bureau of Economic Research (NBER) possui um comitê de datação de ciclos para os Estados Unidos. No período de 1945 a 2008, ou seja, um período isento de depressões e de espirais viciosas, o NBER (2010) identificou 112 meses de recessão distribuídos em 11 ciclos - o que mostra a repetição desse tipo de evento ao longo da história e o potencial de aprendizado nele contido.

Por outro lado, um movimento recessivo que coloca a economia numa trajetória de depressão é aquele que promove uma liquidação supreendentemente profunda e com movimentos retroalimentados e erráticos nos níveis de outras variáveis representativas (níveis de emprego e crédito, por exemplo). A espiral viciosa é o movimento de conformação da depressão e essa, por sua vez, configura um quadro excepcional, extraordinário, fora do comum econômico, em que os agentes não reconhecem segurança no ambiente para a tomada de decisões. Quedas surpreendentemente profundas e erráticas são sinônimos de um quadro de mais incertezas.

Em um estado de anormalidade econômica, as decisões de certos grupos de agentes (empresários, por exemplo) não correspondem a um padrão esperado. Não há o que se esperar com algum grau de segurança em um ambiente bastante desconhecido. Não existem comportamentos conhecidos porque o evento da depressão não é um evento repetitivo. A previsibilidade é reduzida. A impermanência e a volatilidade dos parâmetros garantem um desenrolar desconhecido de reações e cenários. Essa nebulosidade faz com que os agentes prefiram adotar comportamentos defensivos.

$\mathrm{Na}$ depressão há uma paralisação geral e comportamentos defensivos emergem, tais como a preferência por liquidez. ${ }^{24}$ Consumidores e empresários tendem a evitar o gasto até o momento em que condições mais seguras favoreçam a tomada de decisões

24 Para Keynes, “[...] o desalento e a incerteza relativos ao futuro o qual acompanha um colapso na eficiência marginal do capital naturalmente precipita um agudo crescimento na preferência pela liquidez [...]" (KEYNES, 1973, p. 316). 
de consumir ou investir. Em linguagem futebolística, estabelecem uma retranca devido ao desconhecimento das regras em que o jogo está sendo jogado e, então, passa a ser mais importante evitar gols (perdas) do que fazer gols (promover ganhos). Isso caracterizaria o capitalismo funcionando de forma anormal.

A profundidade dos mergulhos e quão erráticas são as variáveis que provocaram depressões têm variado ao longo do tempo devido às significativas mudanças que ocorreram nas economias capitalistas. Em outras palavras, as normalidades se transformaram ao longo tempo, então as espirais viciosas capazes de quebrar essas normalidades também se transformaram.

$\mathrm{Na}$ Grande Depressão do século passado, a economia norte-americana fez quatro recessões anuais consecutivas (de 1930 a 1933) com uma perda de produto de mais de $26 \%$ e o desemprego alcançou 25\% da força de trabalho (ver Gráfico 1). Na década passada, os Estados Unidos fizeram dois anos de recessão e o produto contraiu aproximadamente 3\%; a Zona do Euro fez três anos de recessões e uma perda de produto de $7,8 \%$. A taxa de desemprego aumentou em todos esses países muito menos que nos anos 1930 (ver Tabelas 1 e 2 e Gráfico 1). Ademais, vale a pena destacar ainda a variável oferta de crédito, que compõe a espiral descrita por Schumpeter: nos Estados Unidos houve retração do crédito doméstico ao setor privado por parte dos bancos de 59,8\% do PIB, em 2008, para 49,3\%, em 2013, e na Zona do Euro tal queda foi de $106,1 \%$, em 2009, para 88,5\%, em 2016 (THE WORLD BANK, 2018).

No Brasil, a espiral viciosa destacada por Schumpeter fez os seguintes movimentos: a recessão contraiu o produto em $8,6 \%$ (entre o $1^{\circ}$ trimestre de 2014 e o último de 2016); a taxa de desemprego cresceu de $6,5 \%$ para 13,7\% (entre o $4^{\circ}$ trimestre de 2014 e o $1^{\circ}$ trimestre de 2017); o saldo das operações totais de crédito à economia teve uma contração em termos reais de 14,3\% (entre dezembro de 2013 e dezembro de 2017) e o saldo das operações de crédito à pessoa jurídica teve uma retração real de $26,9 \%$ no mesmo período. Tal como as economias avançadas analisadas por Schumpeter no seu Business Cycles, o Brasil fez sua espiral viciosa nas três variáveis cruciais por um período de dois a três anos - o que é mais uma indicação do diagnóstico de depressão para a economia brasileira.

Com exceção da Grécia, no Brasil e nos diversos países analisados, as quedas que provocaram a entrada nas trajetórias de depressão têm magnitude menor do que aquelas ocorridas nos anos 1930. Isso ocorreu porque existem leis de seguro-desemprego, sistemas previdenciários e diversos programas sociais (no Brasil, por exemplo, o Programa Bolsa Família) que estabelecem um limite inferior de contração, mas não impediram a saída da normalidade.

Há outro motivo que pode explicar porque, nos dias de hoje, as recessões não foram tão profundas em alguns casos e não precisariam ter sido em outros. Afinal, as 
políticas keynesianas são conhecidas teórica e empiricamente. Os Estados Unidos estabeleceram o New Deal em 1933. E, posteriormente, foram plenamente recuperados com os gastos públicos que sustentaram a participação norte-americana na Segunda Guerra Mundial. ${ }^{25}$

Outro bom exemplo de ação para a manutenção da demanda e da produção, nos anos 1930, foi a política de compra de estoques de café pelo governo brasileiro e posterior queima desses estoques com vistas à recuperação dos preços do produto. Nas palavras de Furtado, “o que importa ter em conta é que o valor do produto que se destruía era muito inferior ao montante da renda que se criava. Estávamos, em verdade, construindo as famosas pirâmides que anos depois preconizaria Keynes" (FURTADO, 2009, p. 275). ${ }^{26}$

A recomendação dos líderes do G-20, nas reuniões de abril e setembro de 2009, é exatamente o reconhecimento de que existem políticas econômicas capazes de conter as quedas do produto. O Brasil, durante o ano de 2009, aplicou tais políticas e obteve sucesso (tal como exposto na nota 19).

A conexão existente entre o ciclo econômico e a depressão foi identificada por Keynes. O economista inglês sabia que os movimentos cíclicos da economia tinham que ser orientados para que as depressões fossem evitadas. Assim, propôs:

o remédio correto para o ciclo econômico não consiste em evitar os booms e assim nos manter permanentemente em uma semidepressão, mas em abolir as depressões e nos manter deste modo permanentemente em quase-boom. (KEYNES, 1973, p. 322)

\section{C) Sintetizando: as relações entre recessão e depressão}

A distinção entre uma depressão (anormal) e uma recessão (normal) é decisiva para o entendimento do que seria a própria depressão. Embora seja enfadonho repetir, cabe lembrar que não existe ainda uma teoria da depressão consagrada na literatura econômica. Apresenta-se a seguir uma síntese do que foi dito sobre o evento da de-

25 Para se ter uma ideia da grandeza do crescimento da economia de guerra nos Estados Unidos, basta verificar que, em 1929, as forças militares norte-americanas tinham 260 mil homens, ou seja, 0,5\% da força de trabalho total. Em 1944, esses números tinham saltado para 11,4 milhões de homens nas forças armadas o que equivalia a $17,3 \%$ da força de trabalho total (BLS, 1948).

${ }^{26}$ E Furtado concluiu: “A diferença real entre inversão líquida e acumulação de estoques invendáveis de café residia em que aquela criava capacidade produtiva e a segunda, não. Entretanto, esse aspecto do problema tem importância secundária em épocas de depressão, as quais se caracterizam pela subocupação da capacidade produtiva já existente. É por essa razão que nessas etapas é muito mais importante criar procura efetiva, a fim de induzir a utilização da capacidade produtiva ociosa, do que aumentar essa capacidade produtiva" (FURTADO, 2009, p. 277). 
pressão e da recessão e uma explicação de como esses fenômenos se relacionam entre si e se diferenciam. Evitou-se repetir referências bibliográficas já mencionadas.

Os ciclos econômicos têm amplitudes diversas, suas causas são internas (como, por exemplo, o superendividamento Ponzi-minskyano) ou externas (por exemplo, uma decisão governamental de contenção de gastos ou de elevação da taxa de juros básica da economia). É amplamente aceito que tais flutuações cíclicas são movimentos aleatórios que têm causas identificáveis.

Mais ainda, os ciclos não têm tido amplitude e frequência regulares. Isso tem revelado que cada flutuação é um fenômeno isolado. Flutuações são variações do produto. E esse é o objeto que deve ser analisado dentro de cada movimento de flutuação. Nos ciclos, variações do produto sempre vêm acompanhadas de variações na oferta de crédito, do investimento e no nível de desemprego - tal como serão qualificadas a seguir.

São as formas que assumem a variação do produto que vão diferir uma recessão de uma depressão. Em uma depressão, o produto é retraído de forma aguda e por um longo tempo. Na recessão, em geral, a contração não é necessariamente aguda, mas é passageira.

Nas recessões, embora haja queda do produto, maior ou menor, o desemprego tende a ser menos (ou pouco) afetado. Uma explicação para esse fato é que, em uma recessão, os empresários sempre atrasam as demissões devido ao custo de readmissão. E, logo que vislumbram a recuperação, não efetivam as prováveis demissões previstas anteriormente. Diferentemente, em uma depressão a taxa de desemprego é bastante afetada - e por um longo tempo. ${ }^{27}$

Economias em depressão não são economias que repetem continuamente eventos de recessão. Muito pelo contrário, essas não foram as experiências passadas. É uma marca de depressões a ocorrência de taxas de crescimento (positivas ou negativas) baixas e voláteis. Portanto, quando ocorre uma taxa de crescimento positiva dentro de uma depressão, isso não indica necessariamente a ocorrência de uma recuperação.

Dentro de uma depressão, nem todo crescimento pode configurar uma verdadeira recuperação. Para haver recuperação tem que haver crescimento econômico forte associado a taxas elevadas de crescimento do investimento. Fazendo referência à saída

${ }^{27}$ Os nossos casos são bons exemplos. Na recessão de 1981-1983 não houve elevação drástica do desemprego. No primeiro ano de recessão, a taxa média de desemprego subiu apenas 1,5 ponto percentual em relação ao ano anterior. Nos últimos dois anos da crise, a taxa se manteve estável, com ligeira tendência de queda. Na recessão de 1990-1992, a taxa média de desemprego do primeiro ano foi de 4,6\% - apenas 1,2 ponto percentual maior que a do ano anterior. A taxa média anual atingiu o seu pico em 1992 com 6,1\% (IBGE/PME, 2016). Diferentemente, o desemprego cresceu de forma aguda na depressão atual. A taxa de desemprego no $2^{\circ}$ trimestre de 2014 foi de 6,8\%; saltou para 13,7\% no $1^{\circ}$ trimestre de 2017 (IBGE/PME, 2016). 
da Grande Depressão, Keynes disse: “o problema da recuperação é principalmente um problema de crescimento do volume de investimentos" (KEYNES, 1981, p. 480).

Uma economia fica paralisada em uma depressão caso não haja uma intervenção externa adequada de resgate e recuperação. Isso ocorre porque espontaneamente os agentes tendem a assumir comportamentos bastante defensivos (não consomem adicionalmente e não investem). Se as forças internas não se movem, caberá às forças externas realizar a recuperação (se e quando for o caso).

$\mathrm{Na}$ depressão, as políticas econômicas correntes perdem o efeito porque os agentes assumem parâmetros comportamentais voláteis e não responsivos. Além disso, as reações dos agentes são lentas porque tudo é desconhecido ou está em fase de reconhecimento. Em decorrência, além de lentas, as reações são acanhadas, já que os agentes não sabem quais são as consequências de suas decisões.

Diferentemente, em uma recessão, meros ajustes de políticas econômicas ou até mesmo o funcionamento normal das instituições existentes recolocam a economia em trajetória de recuperação. Isso ocorre porque os agentes não mudaram seus parâmetros comportamentais: aceitam consumir dentro do seu padrão de normalidade e até mesmo realizam investimentos. É uma característica das recuperações pós-recessivas um forte movimento do investimento em busca do "tempo perdido". Esse é um comportamento identificado empiricamente. ${ }^{28}$

A questão fundamental é, entretanto, saber porque existem recessões que são sucedidas por uma recuperação e, portanto, são recessões normais e recessões que levam economias para as depressões. Essa não é uma conexão fácil de ser estabelecida do ponto de vista empírico. Afinal, somente tivemos três grandes episódios de depressão (1870, 1930 e 2008 em diante). Cabe destacar que a depressão de 1870 não possui muitas estatísticas e grande parte das estatísticas norte-americanas foram construídas após e em virtude da depressão de 1930.

A questão precisa a ser respondida é porque, por um lado, há choques que retiram a economia da sua trajetória de crescimento e a colocam em estado de paralisia e, por outro, há choques que não são capazes de causar tal dano. A resposta foi dada por Schumpeter e Keynes. Schumpeter fez uma descrição do comportamento de variáveis

${ }^{28}$ Os nossos casos também são bons exemplos. Nos três anos posteriores à recessão de 1981-1983, o crescimento médio anual da formação bruta de capital fixo foi de 10,5\% (IPEA, 2018). A economia voltou a crescer a taxas elevadas a partir do $2^{\circ}$ trimestre de 1983 por 17 trimestres consecutivos, ou seja, a reação não demorou muito para ocorrer. Nos anos de 1990-1992, a reação à recessão foi também igualmente forte. A taxa média de crescimento dos investimentos nos anos de 1993-1995 foi de 9,3\% (IPEA, 2018). A economia voltou a crescer forte a partir do $2^{\circ}$ trimestre de 1992 por 12 trimestres consecutivos. Tais cenários configuram que a insuficiência de demanda não foi prolongada e que o comportamento dos investimentos é um sintoma crucial de uma recuperação. 
e Keynes fez uma descrição de comportamentos de indivíduos que teriam implicações em uma variável-chave, o investimento.

Schumpeter fez uma observação sobre a permanência da crise recessiva. Segundo ele, quando a recessão traz por um longo período declínios erráticos e agudos da oferta de crédito e do desemprego, está configurada a existência de uma espiral viciosa. Segundo Schumpeter, tal espiral é a marca de uma depressão. Contudo, o economista austríaco foi além. Ele fez referência exatamente à mesma ideia utilizada por Keynes/ Marshall quando disse que a existência da espiral viciosa é sinônimo de mudança de uma situação normal para uma situação anormal.

A recessão, devido à perda social que causa, é indesejada, mas é um evento normal. Os agentes econômicos estão programados para reagir em condições de normalidade (consumindo e investindo). Na depressão, por desconhecimento do ambiente e devido às perdas incorridas, a incerteza se eleva drasticamente, os agentes tendem à paralisia - característica crucial da anormalidade. A depressão não é um evento que tenha se repetido ao longo do tempo. Se não há repetição, não há aprendizado. Portanto, a previsibilidade durante o longo processo depressivo é reduzida.

Na visão de Keynes, a economia entrou em depressão nos anos 1930 porque uma variável saiu de cena, os investimentos. Keynes avaliava que "a máquina tinha sido meramente travada como resultado de uma confusão" (KEYNES, 1933, p. 139). Estaria travada porque teve um problema no seu partidor (chamado de magneto). A questão, então, era como dar novamente a partida na máquina. Então, era preciso religar a máquina a partir do seu partidor, que eram os investimentos de capital.

Para Keynes, a recuperação somente viria, ou seja, a máquina somente seria religada quando os investimentos voltassem. Contudo, avaliava que "um golfo [...] foi colocado entre as ideias dos emprestadores e dos tomadores para o propósito de investimento de capital genuinamente novo" (KEYNES, 1933, p. 145). Mas Keynes, enfatizou:

[...] não pode existir uma verdadeira recuperação, em meu julgamento, até que as ideias de emprestadores e tomadores produtivos sejam colocadas juntas novamente; em parte, emprestadores se tornando dispostos para emprestar em termos mais amigáveis e para um espaço geográfico mais amplo, e em parte, tomadores recuperando seus bons espíritos e, então, se tornando mais dispostos a tomar emprestado. (KEYNES, 1933, p. 145, grifos nossos)

A questão então era: por que emprestadores e tomadores (investidores) mudaram significativamente suas ideias que se tornaram tão divergentes? A resposta está na construção teórica elaborada por Cardim de Carvalho baseada em Keynes/Marshall e utilizada para explicar o deslizamento de uma economia para uma depressão: 
Quando os choques reais são maiores que aqueles previamente julgados normais, eles ultrapassam as defesas construídas pelos agentes de tal forma que a economia não pode funcionar com sua operação regular. Como resultado, os agentes sentem a necessidade de revisar suas teorias de como as coisas funcionam "normalmente", portanto, mudam os parâmetros que definem "normalidade". (CARDIM DE CARVALHO, 2016, p. 457)

Portanto, concluiu Cardim de Carvalho:

Dentro desse arcabouço, a depressão começa quando um choque adverso é suficientemente grande para ultrapassar as barreiras construídas pelas unidades econômicas, tornando impossível para eles manter seus padrões de comportamento e/ou suas teorias da economia. (CARDIM DE CARVALHO, 2016, p. 458)

Sendo assim, a depressão se diferencia da mera recessão não somente devido à sua permanência e profundidade, mas sim devido a uma mudança comportamental dos agentes econômicos que paralisam a economia em um estado de produto contraído e elevado de desemprego. A depressão ocorre quando as defesas institucionais, de política econômica e comportamentais, não foram suficientes para conter um choque negativo, represando-o no nível de uma recessão ou de uma desaceleração. Portanto, iniciada a depressão, não há mais como contar com as forças internas (consumidores e investidores) para religarem o magneto.

\section{COMO O BRASIL MERGULHOU NA DEPRESSÃO}

A porta de entrada da depressão dos anos 1870 e da Grande Depressão dos anos 1930 foram pânicos causados por quebras das bolsas de valores. Em ambos os casos, a perda de riqueza colapsou o sistema financeiro seja porque os perdedores queriam sacar suas poupanças, seja porque os perdedores eram os próprios bancos. ${ }^{29} \mathrm{O}$ colapso de sistemas financeiros provoca recessões devido à contração do crédito.

${ }^{29}$ Nas duas grandes crises, o movimento foi semelhante. Foram precedidas de fases de prosperidade, euforia e especulação. Os sinais de insustentabilidade eram desconsiderados. Entretanto, chegaram os dias que se tornaram o símbolo do fim das "bolhas de riqueza" e o início das depressões. Após quedas extraordinárias, a Bolsa de Viena, epicentro da primeira depressão, fechou por três dias em maio de 1873. Por cinco dias consecutivos em outubro de 1929, o valor dos preços das ações despencou na Bolsa de Nova Iorque. 
Na depressão iniciada em 2007-2008 nos Estados Unidos, a perda abrupta de riqueza também envolveu o sistema financeiro. ${ }^{30}$ Posteriormente, na Zona do Euro, a desconfiança de que governos que tinham elevadas dívidas não honrariam seus compromissos, com potencial perda de riqueza para grande parte da sociedade, revelou em paralelo que bancos não eram tão sólidos quanto pareciam, e o clima de perda potencial de riqueza arrastou o sistema financeiro para a crise. ${ }^{31}$

Além de crises no sistema financeiro que colapsam a oferta de crédito, diversos outros fatores podem causar uma recessão. ${ }^{32}$ Recessões podem ser normais ou podem compor uma espiral viciosa. O mais importante para explicar a existência de uma depressão não é a causa da recessão que compõe a sua espiral viciosa, mas a própria existência da espiral. Então, não é necessário haver um colapso financeiro para que seja caracterizada uma depressão, mas sim uma queda persistente do produto-emprego-crédito de forma abrupta, errática e retroalimentada.

O Brasil não enfrentou um colapso do sistema financeiro em 2014. Ao contrário, o sistema financeiro brasileiro tem se mostrado sólido e lucrativo nas últimas décadas. Contudo, os bancos contraíram o crédito durante a queda do produto e do emprego (de 2015 e 2016), o que conformou, de forma plena, a espiral viciosa brasileira. A entrada da economia brasileira na depressão, que ocorreu em meados de 2014, foi construída (i) pelas políticas econômicas iniciadas em 2011; (ii) pelas políticas e reformas colocadas em prática a partir de 2015; (iii) por uma crise política; e (iv) por uma operação judicial/econômica.

\section{i - Políticas econômicas iniciadas em 2011}

Houve, a partir de 2011, a troca de políticas de administração da demanda por políticas de administração do lado da oferta ${ }^{33}$ e, além disso e desde então, foram for-

30 A crise de 2007-2008 teve início com a disseminação da inadimplência no mercado imobiliário dos Estados Unidos. Os títulos que estavam lastreados nos financiamentos imobiliários tiveram uma queda vertiginosa dos seus preços. Bancos que possuíam tais títulos quebraram ou se retraíram.

${ }^{31}$ Governos que tinham elevadas dívidas públicas tiveram que enfrentar um crescimento adicional dos seus passivos porque houve queda de receitas devido à recessão de 2009 (e posterior crise do produto) e, ainda, eram obrigados a remunerar seus credores com taxas de juros mais elevadas para que pudessem ser refinanciados. E mais: alguns governos tiveram que socorrer bancos que se envolveram em operações de empréstimos imobiliários duvidosos e que também possuíam títulos de liquidez igualmente duvidosa (inclusive de governos excessivamente endividados).

${ }^{32}$ Crises cambiais, queda acentuada de preços de commodities, políticas econômicas contracionistas e grave instabilidade política também podem causar recessões (entre outros fatores).

33 Políticas pelo lado da oferta buscam, principalmente, a redução de custos das empresas visando ao aumento de competitividade (redução de impostos, por exemplo) ou, ainda, ao aumento potencial de produtividade de todos os fatores de produção (por exemplo, melhoria dos sistemas educacionais voltando-os para o mercado de trabalho). Políticas de administração de demanda buscam reduzir diretamente o desemprego 
matadas ações fiscais de acordo com a visão da reunião de 2010 de líderes do G-20. Esse pode ser considerado o mais importante canal de transmissão da crise internacional para a economia brasileira, ou seja, a adoção de modelos de funcionamento para a economia baseados em redução de custos empresariais (melhoria da competitividade) e readequação da administração fiscal (políticas de austeridade e reformas estruturais). Tal modelo, como será visto no próximo item, foi consolidado e aprofundado a partir de 2015. A contaminação brasileira veio mais pelo canal da cópia/imitação de políticas e reformas aplicadas no exterior (Europa Ocidental, por exemplo) do que por canais da economia real. ${ }^{34}$ É provável que tal modelo seja ainda mais aprofundado a partir de 2019.

Foram inúmeras as medidas colocadas em prática dentro do arcabouço das políticas pelo lado da oferta, mas se destacaram: extensos programas de desonerações fiscais empresariais, redução do spread bancário e diminuição das tarifas de energia elétrica. ${ }^{35}$ Desonerações fiscais empresariais representam a essência da adoção de políticas pelo lado da oferta em oposição às políticas de administração da demanda. Nesse caso, o governo abriu mão de recursos e de sua capacidade de impulsionar a economia com o objetivo de reduzir custos das empresas (talvez na esperança de que empresários optassem por fazer investimentos com os recursos que deveriam ter sido recolhidos na forma de tributos). ${ }^{36}$

A busca pela consolidação fiscal apregoada na reunião de líderes do G-20 de 2010 apareceu com ações pontuais durante o período 2011-2014. Tais ações tiveram possivelmente um efeito de redução do estímulo que o governo dava ao crescimento da economia. Entre as ações pontuais são destaques a meta de superavit primário de 2011

(com investimento públicos, por exemplo) e estimular as expectativas de lucro empresarial (incentivando a demanda de bens de consumo, por exemplo).

${ }^{34}$ A queda do preço das commodities, ocorrida entre 2014 e 2016, pode ter tido também alguma influência recessiva. Afinal, as exportações de commodities representam 63\% da pauta brasileira. (UNCTAD, 2016). Os três principais produtos de exportação são: soja, minério de ferro e petróleo. O preço da soja caiu mais de 37\% entre março de 2014 e março de 2016, e os do petróleo e do minério de ferro, mais de 60\% no mesmo período (IPEA, 2018) Segundo relatório do Itaú-BBA (2015), existe uma tendência secular de queda do preço das commodities e que a queda que ocorreu entre 2011 e 2014 fez os preços voltarem para essa trajetória. Contudo, a redução de preços de 2015 e meados de 2016 colocou os preços das commodities abaixo da sua tendência secular, aliás, tal como o relatório previa que poderia acontecer. Contudo existe argumento que amenizaria o impacto dessa influência recessiva: a exportação de commodities representa apenas $6,8 \%$ do PIB (UNCTAD, 2016).

${ }^{35}$ Uma detalhada e extensa lista das medidas econômicas adotadas nesse período pode ser encontrada em Singer (2015, p. 47-49).

${ }^{36}$ Em conversa que o autor teve com o presidente Lula em novembro de 2017, o presidente disse que não sabia porque tinham transformado as desonerações, que eram para ser pontuais e momentâneas, em coisa ampla e permanente. 
do governo central, que foi aumentada em quase R\$ 10 bilhões, ${ }^{37}$ e o início da discussão sobre uma reforma da Previdência. ${ }^{38}$

A intenção de redução das ações fiscais de gastos do governo foi evidenciada pela redução da taxa de crescimento dos investimentos do governo central e de suas estatais quando são comparados os períodos 2007-2010 e 2011-2014. Houve uma queda brutal de um período para o outro (ver Tabela 3). Pode-se, ainda, perceber essa intenção reducionista quando se compara o crescimento médio do PIB de 2,35\% ao ano no período 2011-2014 com as taxas reduzidas de crescimento dos investimentos federais (governo e estatais) desse período (ver Tabela 3). Durante os anos em que isso ocorreu, não se sabe exatamente qual foi o saldo das ações fiscais sobre o produto, mas na rubrica de maior discricionariedade e que possui o maior multiplicador (os investimentos públicos), o governo agiu no sentido da consolidação fiscal sugerida pelo G-20 em 2010. ${ }^{39}$

\section{Tabela 3 - Taxas médias reais anuais de crescimento do PIB e dos gastos do governo nos períodos 2007-2010 e 2011-2014, em \%}

\begin{tabular}{lccc}
\hline Anos & $\begin{array}{c}\text { Crescimento do PIB } \\
\text { (média anual) }\end{array}$ & $\begin{array}{c}\text { Investimento do Governo } \\
\text { Central } \\
\text { (média anual) }\end{array}$ & $\begin{array}{c}\text { Investimento das Estatais } \\
\text { Federais } \\
\text { (média anual) }\end{array}$ \\
\hline $2007-2010$ & 4,64 & 26,04 & 23,52 \\
$2011-2014$ & 2,35 & 1,03 & 1,5 \\
\hline
\end{tabular}

Fonte: IBGE/SCNT (2018) e cálculos elaborados pelo autor com base nos dados de Orair (2016).

37 "A parte do governo federal é aproximadamente R\$ 81 bilhões. Eu estou anunciando um aumento para R\$ 91 bilhões de [superávit] primário a ser realizado em 2011. Ou seja, [quase] R \$ 10 bilhões a mais de resultado primário que nós vamos cumprir em 2011", disse o ministro da Fazenda, Guido Mantega, em agosto de 2011 (AGÊNCIA BRASIL, 2011).

${ }^{38} \mathrm{O}$ ministro da Previdência Social do governo Dilma Rousseff, Garibaldi Alves, poucos dias antes de sua posse, começou a propagandear a necessidade de haver uma reforma previdenciária (SENADO, 2010), e, durante toda a sua gestão, manteve tal propaganda.

39 Um dos maiores multiplicadores de gastos públicos é o do gasto de investimento (ver, por exemplo, ORAIR, SIQUEIRA e GOBETTI, 2016). Isso implica dizer que, embora seja ressalvado que o resultado de todas as ações fiscais possa não ter sido reducionista no período 2011-2014, a simples troca de investimentos públicos (política de administração da demanda) por subsídios (política pelo lado da oferta) “[...] reforça a ideia sugerida pela análise descritiva de que a mudança no mix da política fiscal entre 2008-2010 e 2011-2014, caracterizada pela redução dos investimentos e expansão dos subsídios, tenha sido uma má escolha e ajude a explicar a baixa resposta da economia aos estímulos concedidos pelo governo" (ORAIR, SIQUEIRA e GOBETTI, 2016) - os autores concluíram que os subsídios têm um multiplicador "insignificante ou pouco persistente, qualquer que seja a situação econômica". 


\section{ii - Políticas econômicas a partir de 2015}

No início de 2015, o Brasil adotou de forma declarada políticas de austeridade para supostamente combater uma crise fiscal iniciada em $2014 .{ }^{40} \mathrm{O}$ governo chamou aquele conjunto de políticas de ajuste fiscal. Foram adotadas medidas para reduzir os gastos do governo. Cortes de gastos públicos foram feitos em todas as áreas. ${ }^{41} \mathrm{E}$, além disso, duas Medidas Provisórias (MP no 664/2015 e MP no 665/2015) foram enviadas ao Congresso Nacional e, logo em seguida, foram aprovadas. Tais MP reduziram o acesso ao seguro-desemprego e a benefícios da Previdência Social.

Em 2015, os investimentos do governo central caíram em relação ao ano anterior, 37,9\%, e das suas estatais caíram 25,2\% (ORAIR, 2016). ${ }^{42}$ Paralelamente, o Banco Central do Brasil elevou a taxa de juros básica da economia (Selic). De janeiro a dezembro de 2015 , a Selic subiu de $10,5 \%$ ao ano para $14,25 \% .{ }^{43}$ Com políticas monetária e fiscal contracionistas, o resultado esperado não poderia ser outro senão o mergulho da economia na depressão.

Em março de 2016, o governo enviou ao Congresso um Projeto de Lei Complementar que limitaria os gastos do governo de acordo com uma proporção do PIB - as metas anuais deveriam ser fixadas no Plano Plurianual (PPA) e a Lei de Diretrizes Orçamentárias (LDO) fixaria o valor nominal em cada ano. Havia uma clara intenção do governo de reduzir os

${ }^{40}$ O diagnóstico da existência de uma crise fiscal (em 2014) é um ponto de controvérsia. Afinal, 2014 tinha sido o primeiro ano, desde o início da série divulgada pelo Banco Central, que é de 2002, que o setor público fez um deficit primário. Em 2014, o resultado primário foi deficitário em apenas 0,57\% do PIB e os juros nominais atingiram um pagamento de 5,47\% do PIB (devido às elevadas taxas de juros Selic). Logo, o deficit nominal foi de 6,04\% do PIB (BCB, 2018). Ademais, tinha havido uma queda de receitas do governo de aproximadamente $2 \%$ em termos reais devido à desaceleração econômica - o PIB cresceu 0,5\% naquele ano (BRASIL, 2018). Não existiria, então, um desequilíbrio fiscal estrutural, crescente e repetitivo. Houve um desequilíbrio conjuntural, pontual, causado pelos juros elevados e pela queda de receitas do governo.

${ }^{41}$ No início da Grande Depressão, muitos “[...] deram apoio a Andrew Mellon, o secretário do Tesouro do presidente Robert Hoover, e à sua tentativa de restaurar o equilíbrio fiscal: a recessão causara uma queda na arrecadação de impostos mais acelerada que a dos gastos. Para restaurar a 'confiança', segundo acreditavam os conservadores fiscais de Wall Street, era necessário cortar gastos, um após o outro" (STIGLITZ, 2010, p. 342).

${ }^{42}$ Houve também corte de gastos de consumo do governo. Caíram de forma contínua, de 151,27 (índice adimensional), no $3^{\circ}$ trimestre de 2014 , para 147,28 no $4^{\circ}$ trimestre de 2017 , ou seja, $2,6 \%$ no período (IBGE/SCNT, 2018).

43 Essa elevação dos juros foi justificada devido ao aumento da inflação (de 10,67\% ao longo de 2015), que, por sua vez, foi causada, em grande parte, pelo aumento autorizado pelo governo dos preços da gasolina (de 20,1\%), do etanol (de 29,6\%) e da energia elétrica (de 51\%). O conjunto de preços monitorados subiu 18,1\% em 2015 O custo fiscal da elevação dos juros, em nome do controle da inflação, foi muito alto. Naquele ano, o deficit nominal do setor público foi de $10,34 \%$ do PIB, sendo o deficit primário de $1,88 \%$ do PIB e os restantes $8,46 \%$ ocorreram devido ao pagamento de juros da dívida pública (BCB, 2018). 
gastos públicos como proporção do PIB. Esse projeto previa até medidas automáticas caso o governo ameaçasse não cumprir as metas: desde a vedação de concessão de aumentos de remuneração acima do índice de inflação para servidores até o congelamento do valor real do salário mínimo ou a demissão incentivada de funcionários públicos.

O Projeto de Lei foi preterido por uma proposta de Emenda Constitucional que terá efeito semelhante. Em dezembro de 2016, por iniciativa do governo, foi aprovada a Emenda Constitucional $n^{\circ} 95$, que estabeleceu o congelamento do nível de gastos reais do governo federal por vinte anos.

Há uma séria implicação decorrente seja do Projeto de Lei Complementar (não examinado pelo Congresso), seja da Emenda Constitucional no 95 aprovada, para o estabelecimento de uma política de recuperação da depressão: a política fiscal de aumento de gastos principalmente com investimentos não poderá ser utilizada para esse fim. Em sentido oposto, essa foi a principal recomendação de Keynes para a superação da depressão dos anos 1930: "é de máxima importância que as autoridades públicas deveriam reviver seus programas de gastos de capital em todas as frentes úteis o mais breve possível e na maior escala possível” (KEYNES, 1982, p. 126).

\section{iii - A crise política}

O Ministro da Fazenda, Joaquim Levy, em setembro de 2015, fez uma afirmação certeira. Disse ele:

O ajuste econômico, do ponto de vista clássico, explica talvez um terço da desaceleração do PIB. PIB é a soma de uma porção de decisões. Quando tem uma turbulência política as pessoas se retraem. E decisões que você precisa tomar são adiadas. (EL PAÍS, 2015)

A proporção (de um terço) indicada pelo Ministro foi mera força de expressão, não é possível ser calculada. Contudo, a crise política era (e é) grave e teve influência sobre a recessão do ano de 2015.

A crise política instaurada no país, desde o resultado das eleições presidenciais de 2014, teve início com o não reconhecimento político por parte da oposição da vitória eleitoral da presidente eleita Dilma Rousseff. ${ }^{44}$

Posteriormente, o presidente da Câmara dos Deputados, Eduardo Cunha, e o candidato derrotado, senador Aécio Neves, organizaram uma ampla oposição ao governo eleito dentro do Congresso Nacional. Iniciativas do governo não eram aprovadas no Congresso (ou tramitavam lentamente na casa legislativa), mas as propostas oposicio-

\footnotetext{
${ }^{44}$ Ver artigo de Coimbra (2014), em que autor destacou que a elite brasileira e o candidato derrotado, Aécio Neves, continuaram em campanha mesmo após o fim das eleições de 2014.
} 
nistas eram aprovadas (ou estavam sempre na iminência de serem aprovadas para serem utilizadas como instrumento político de ameaça). ${ }^{45}$

A crise política se aprofundou com a abertura de processo de impeachment da presidente Dilma Rousseff, em 2 de dezembro de 2015. A presidente foi acusada de cometer crime na área contábil devido a operações indevidas de instrumentos fiscais. $\mathrm{O}$ vice-presidente Michel Temer participou da trama política oposicionista, fazendo inclusive articulações para afastar a presidente. Em 31 de agosto de 2016, Dilma Rousseff foi afastada. Mas a crise política continuou.

Durante o ano de 2015 havia um clima de comoção e tensão nacional. Em paralelo à crise política no Congresso Nacional, outros eventos políticos críticos eram noticiados de forma intensiva na grande mídia. A principal fonte da grande mídia era a Operação Lava Jato (tratada no próximo item), que lançava suspeitas de corrupção sobre membros do governo e seus aliados.

Keynes explicou em sua Teoria Geral que o clima político é, de fato, elemento importante para a formação de expectativas dos empresários. Não somente os cálculos matemáticos formam a base para a tomada de decisões, mas principalmente o entusiasmo individual. A consequência, segundo Keynes, era que

[...] não somente as quedas e as depressões têm a sua intensidade agravada, mas que a prosperidade econômica dependente excessivamente de uma atmosfera política e social que seja satisfatória para o empresário comum. [...] Na estimativa de investimentos futuros, temos que considerar, portanto, os nervos e a histeria e até mesmo as digestões e reações [dos empresários às condições existentes]. (KEYNES, 1973, p. 162)

Os cenários políticos de 2015 e 2016 eram de instabilidade e insegurança. O governo se revelava fraco e, portanto, não podia assegurar uma trajetória de prosperidade econômica. As digestões e reações empresariais àquelas condições eram de desânimo. As decisões de investimentos privados se retraíram. A queda do investimento total foi de aproximadamente $28 \%$ nesses dois anos (IBGE/SCNT, 2018).

\section{iv - A operação judicial/econômica}

A conhecida Operação Lava Jato contribuiu com o agravamento da crise política por meio de inúmeras ações, por exemplo, a divulgação de diálogos telefônicos entre a

45 O ano de 2015 foi marcado pela pressão política sofrida pelo governo das chamadas "pautas-bomba". Nelas, a maioria do Congresso impunha novas despesas para o governo por meio, por exemplo, da concessão de reajustes a segmentos do funcionalismo público e impedia a votação de projetos que possibilitariam aumentos da receita. Para mais detalhes, ver Folha de São Paulo (2015). 
então presidente Dilma Rousseff e o ex-presidente Luís Inácio Lula da Silva. A Polícia Federal, por ordem judicial, gravou clandestinamente as comunicações telefônicas entre os ex-presidentes, e o juiz federal que comandava a operação colocou as ligações interceptadas à disposição da imprensa nacional na tarde do dia 16 de março de 2016. A interpretação induzida pela grande mídia ao público era de que Dilma e Lula estariam tentando dificultar a ação da Justiça.

A evidente parceria entre a grande mídia e os operadores da Lava Jato colaborou para o agravamento da crise política por meio de noticiários "pirotécnicos" daquilo que foi rotulado como escândalos de corrupção. Esse tipo de noticiário ocorreu quase que de forma permanente ao longo dos anos de 2015 e $2016 .^{46}$

A atuação da Operação Lava Jato não foi somente no campo político, mas também e diretamente sobre o ambiente econômico em importantes cadeias produtivas. A Consultoria GO e a Tendências Consultoria estimaram que 2,5 pontos percentuais da recessão de 2015 (que foi de 3,8\%) ocorreram por conta dos efeitos da Operação (VALOR, 15/08/2016; BBC, 15/12/2015). As grandes empreiteiras e a Petrobras, que formam importantes cadeias produtivas, foram as principais atingidas pela Operação Lava Jato. Esses dois segmentos (petróleo/gás e construção civil) foram alvo de 22 ações (ou fases) da operação entre 2014 e 2016 (KLIASS, 2017).

\section{CONSIDERAÇÕES FINAIS}

As maiores economias entraram em crise em 2008-2009. A crise tem as principais características das depressões de 1870 e 1930: quedas acentuadas do produto e do emprego e uma insuficiência de demanda prolongada. As taxas de desemprego e o produto pré-crise ainda não foram recuperados para grande parte dos países envolvidos. Contudo, o biênio 2017-2018 parece ter sido bem mais favorável.

Economias médias e pequenas também entraram em crise nos últimos anos, por exemplo, Rússia, Argentina, Equador e Brasil. O Brasil entrou em depressão. Na passagem de 2013 para 2014, começaram a aparecer os primeiros sinais da desaceleração brasileira. Teve início uma trajetória de redução da utilização da capacidade instalada e do investimento. Durante o ano de 2014, a economia entrou em recessão rumo à depressão. Houve redução do número de trabalhadores com carteira assinada no setor privado e queda aguda da taxa de crescimento do estoque de capital rumo à estagnação dessa variável.

\footnotetext{
${ }^{46}$ Para um conhecimento de alguns detalhes da relação da Operação Lava Jato com a grande mídia, ver Carllotti (2016).
} 
A recessão brasileira, diferentemente do que ocorreu em outros episódios de depressão, não foi provocada por um colapso do sistema financeiro. Muito pelo contrário, seu sistema financeiro se mostra sólido e lucrativo. No Brasil houve mudança da política econômica praticada até 2010 para um modelo de política pelo lado da oferta associado à busca de redução dos gastos públicos como proporção do PIB. Além disso, a partir de 2015 foram adotadas políticas de austeridade, o país mergulhou em uma profunda crise política e a Operação Lava Jato contribuiu para o agravamento dessa crise, assim como fez com que cadeias produtivas importantes fossem atingidas (construção civil e petróleo/gás).

Em 2017, a economia cresceu 1\%. Contudo, esse crescimento parece não fazer parte de uma trajetória de recuperação rumo à expansão e, portanto, de superação completa da depressão. Não existiriam canais de recuperação da demanda que mostram força e permanência, apesar do enorme espaço para o crescimento devido à capacidade ociosa existente e à carência de investimentos, principalmente em infraestrutura. O crescimento da economia brasileira em 2017 parece se assemelhar àqueles experimentados, por exemplo, pela Itália ou Espanha nos últimos anos. Taxas de crescimento (positivas ou negativas) baixas e voláteis caracterizam os movimentos dentro de um estado de depressão.

O FMI tem uma previsão otimista para economia brasileira: “[...] deverá melhorar para 2,3\% em 2018 e 2,5\% em 2019, impulsionada pelo consumo privado e investimento mais fortes" (IMF, 2018, p. 17). Ainda que as previsões do Fundo se realizem, em 2020 o Brasil ainda não terá recuperado o PIB de 2014. Entretanto, para que o consumo aumente, será necessário que a taxa de desemprego se reduza velozmente, já que aumentos reais nos rendimentos dos trabalhadores não estão ocorrendo, de acordo com a PNAD do IBGE (IBGE/PNAD Contínua, 2018). Segundo a mesma pesquisa, a taxa de desemprego também se mostra resistente a baixas aceleradas.

A outra aposta do FMI é nos investimentos "mais fortes”. Do setor público não poderão vir, na medida em que a Emenda Constitucional no 95 impôs um congelamento para os gastos públicos. Do setor privado, ainda não foram emitidos sinais nessa direção.

Não surgiram ainda indicadores animadores. A depressão é um fenômeno de longa duração, principalmente quando não são aplicadas políticas de recuperação por meio de gastos públicos. Essa é a experiência histórica.

Cabe, por último, destacar que, em conjunto com o desenvolvimento dos argumentos empíricos que apoiaram a conclusão de que o Brasil vive uma depressão, foram lançados argumentos teóricos com o objetivo da construção de uma teoria da depressão na mesma linha do artigo de Cardim de Carvalho (2016). Portanto, o presente trabalho buscou adicionar à literatura econômica uma caracterização histórica e real da economia brasileira, assim como delinear um esboço de teoria da depressão. 


\section{REFERÊNCIAS}

AGÊNCIA BRASIL. Brasil eleva meta de superávit primário a R 91 bi em 2011 para acelerar queda dos juros. Agência Brasil, 29 ago. 2011. Disponível em: <http://www.brasil.gov.br/ economia-e-emprego/2011/08/meta-de-superavit-primario-do-governo-central-este-ano-aumenta-para-cerca-de-r-91-bilhoes >. Acesso em: 15 abr. 2018.

ALLEN, K. Greek debt crisis: the 20 key moments. The Guardian, 25 jun. 2015. Disponível em: $<$ https://www.theguardian.com/business/2015/jun/25/greek-crisis-20-key-moments-eurozone>. Acesso em: 14 abr. 2018.

BCB - BANCO CENTRAL DO BRASIL. Sistema gerenciador de séries temporais. Brasília: Banco Central do Brasil [citado em 30 mai. 2018]. Disponível em: <https://www3.bcb.gov.br/sgspub/localizarseries/localizarSeries.do?method=prepararTelaLocalizarSeries $>$. Acesso em: 30 mai. 2018.

BARCA, A. J.; JIMÉNEZ, C. Levy: “Ajuste fiscal explica um terço da queda do PIB. O resto é nó político”. El País, 07 set. 2015. Disponível em:<https://brasil.elpais.com/brasil/2015/09/04/ politica/1441399950_475629.html>. Acesso em: 11 abr. 2018.

BEA - BUREAU OF ECONOMIC ANALYSIS. Data. Washington, D.C.: U.S. Department of Commerce [citado em 30 mai. 2018]. Disponível em: <https://www.bea.gov/>. Acesso em: 30 mai. 2018.

BLS - BUREAU OF LABOR STATISTICS. Labor force, employment, and Unemployment, 192939: Estimating Methods. Washington, D.C.: Bureau of Labor Statistics, 1948. Disponível em: <https://www.bls.gov/opub/mlr/1948/article/pdf/labor-force-employment-and-unemployment-1929-39-estimating-methods.pdf>. Acesso em: 06 mar. 2018.

BLINDER, A; ZANDI, M. How the Great Recession was brought to an end. Moody's Analytics, 27 Jul. 2010. Disponível em: <https://www.economy.com/mark-zandi/documents/End-of-Great-Recession.pdf>. Acesso em: 09 dez. 2018.

BRASIL. Receita Federal. Relatórios do Resultado da Arrecadação. Brasília: Ministério da Economia [citado em 30 mai. 2018]. Disponível em: <http://receita.economia.gov.br/dados/receitadata/arrecadacao/relatorios-do-resultado-da-arrecadacao>. Acesso em 30 mai. 2018.

CARDIM DE CARVALHO, F. Is this 'it'? An outline of a theory of depression. Brazilian Journal of Political Economy, v. 36, n. 3, p. 451-469, jul./set., 2016.

CARDIM DE CARVALHO, F. Mr. Keynes and the Post-Keynesians. Chetelhan: Edward Elgar, 1992.

CARLOTTI, T. Vazamentos seletivos: o conluio entre mídia e Lava Jato. Carta Maior, 08 abr. 2016. Disponível em: <https://www.cartamaior.com.br/?/Editoria/Politica/Vazamentos-seletivos-o-conluio-entre-midia-e-Lava-Jato/4/35911>. Acesso em: 17 abr. 2018.

COIMBRA, M. Aceitar os fatos. Carta Capital, 10 dez. 2014. Disponível em: <https://www. cartacapital.com.br/revista/829/aceitar-os-fatos-3950.html>. Acesso em: 16 abr. 2018.

CNI - CONFEDERAÇÃO NACIONAL DA INDÚSTRIA. Indicadores industriais. Atividade Industrial. Brasília: Portal do Sistema Indústria [citado em 30 mai. 2018]. Disponível em: <http://www6.sistemaindustria.org.br/gpc/externo/listaResultados. faces? codPesquisa=100>. Acesso em 30 mai. 2018. 
COGGIOLA, O. As grandes depressões: 1873-1896 e 1929-1939. São Paulo: Alameda Casa Editorial, 2009.

COSTAS, R. Escândalo da Petrobras "engoliu 2,5\% da economia em 2015". BBC Brasil, São Paulo, 02 dez. 2015. Disponível em: <http://www.bbc.com/portuguese/ noticias/2015/12/151201_lavajato_ru>. Acesso em: 11 abr. 2018.

DOBB, M. A evolução do capitalismo. São Paulo: Abril Cultural, 1983.

EICHENGREEN, B.; O'ROURKE, K. What do the new data tellus? VOX, 08 mar. 2010. Disponível em: <https://voxeu.org/article/tale-two-depressions-what-do-new-data-tell-usfebruary-2010-update>. Acesso em: 09 dez. 2018.

FARIA, A. Garibaldi considera ser necessária nova reforma da Previdência. Rádio Senado, Brasília, 30 dez. 2010. Disponível em: <https://www12.senado.leg.br/radio/1/noticia/garibaldiconsidera-ser-necessaria-nova-reforma-da-previdencia >. Acesso em: 17 abr. 2010.

FATÁS, A. "The effects of business cycles on growth". In: LOAYZA, N.; SOTO, R. (Orgs.). Economic growth: sources, trends, and cycles. Santiago: Central Bank of Chile, 2002. Disponível em: <http://si2.bcentral.cl/public/pdf/banca-central/pdf/v6/191_220fatas.pdf>. Acesso em: 20 mar. 2018.

FOLHA DE SÃO PAULO. Saiba o que são as pautas-bomba nas mãos do Congresso contra o governo. Folha de São Paulo, São Paulo, 05 ago. 2015. Disponível em: <http://www1.folha. uol.com.br/mercado/2015/08/1664711-saiba-o-que-sao-as-pautas-bomba-nas-maos-docongresso-contra-o-governo.shtml>. Acesso em: 16 abr. 2018.

FURTADO, C. Formação econômica do Brasil (50 anos - edição comemorativa). São Paulo: Companhia das Letras, 2009.

G-20 SUMMIT. Declaração dos líderes cúpula de Toronto. Toronto: G-20, 2010. Disponível em: <http://www.g20.utoronto.ca/2010/g20_declaration_en.pdf>. Acesso em 26 fev. 2018.

G-20 SUMMIT. Declaração dos líderes cúpula de Pittsburgh. Toronto: G-20, 2009. Disponível em:<http://www.g20.utoronto.ca/2009/2009communique0925-br.html>. Acesso em: 26 fev. 2018.

HIKCS, J. Valor e capital. São Paulo: Abril Cultural, 1987.

IBGE - INSTITUTO BRASILEIRO DE GEOGRAFIA E ESTATÍSTICA. Sistema de Contas Nacionais Trimestrais - SCNT. Rio de Janeiro: IBGE, $3^{\circ}$ trimestre de 2018. Disponível em: $<$ https://www.ibge.gov.br/estatisticas-novoportal/economicas/contas-nacionais/9300contas-nacionais-trimestrais.html?=\&t=downloads $>$. Acesso em: 30 mai. 2018.

IBGE - INSTITUTO BRASILEIRO DE GEOGRAFIA E ESTATÍSTICA. Pesquisa Nacional por Amostra de Domicílios Contínua - PNAD Contínua. 3 ed. Rio de Janeiro: IBGE, 2018. Disponível em: <https://www.ibge.gov.br/estatisticas-novoportal/sociais/trabalho/17270pnad-continua.html?=\&t=series-historicas $>$. Acesso em: 30 mai. 2018.

IBGE - INSTITUTO BRASILEIRO DE GEOGRAFIA E ESTATÍSTICA. Indicadores IBGE. Pesquisa Mensal do Emprego. Fevereiro de 2016. Pesquisa Mensal de Emprego, Rio de Janeiro, 23 mar. 2016. Disponível em: <https://ww2.ibge.gov.br/home/estatistica/ indicadores/trabalhoerendimento/pme_nova/>. Acesso em: 30 mai. 2018. 
ILO - INTERNATIONAL LABOUR ORGANIZATION. Recent experiences of formalization in Latin America and the Caribbean. Geneva: ILO, 2014. Disponível em: <http://www.ilo.org/ wcmsp5/groups/public/---americas/---ro-lima/documents/publication/wcms_245882. pdf>. Acesso em: 09 mar. 2018.

IMF - INTERNATIONAL MONETARY FUND. World Economic Outlook. Washington, D.C.: IMF, Apr. 2018.

IPEA - INSTITUTO DE PESQUISA ECONÔMICA APLICADA. Indicadores IPEA trimestrais de estoque de capital e de investimento líquido. Carta de Conjuntura, IPEA, 11 out. 2017. Disponível em: <http://www.ipea.gov.br/cartadeconjuntura/index.php/tag/estoque-decapital/>. Acesso em: 30 mai. 2018.

IPEA - INSTITUTO DE PESQUISA ECONÔMICA APLICADA. IPEADATA. IPEA [citado em 30 mai. 2018]. Disponível em: < http://www.ipeadata.gov.br>. Acesso em: 30 mai. 2018.

KEYNES, J. M. The collected writings of John Maynard Keynes: Activities 1931-1939: world and politics in Britain and America. v. XXI. London: Macmillan, 1982.

KEYNES, J. M. The collected writings of John Maynard Keynes: Activities 1929-1931: rethinking employment and unemployment policies. v. XX. London: Macmillan, 1981.

KEYNES, J. M. The general theory of employment, interest and money. London: Macmillan, 1973.

KEYNES, J. M. Essays in persuasion. London: Macmillan, 1933.

KALECKI, M. Teoria da dinâmica econômica. São Paulo: Abril Cultural, 1983.

KALECKI, M. "O mecanismo da recuperação". In: MIGLIOLI, J. (Org.). Kalecki. Coleção Grandes Cientistas Sociais. São Paulo: Editora Ática, 1980.

KLIASS, P. A Lava-Jato e a economia devastada, três anos depois. Outras Palavras, 31 mar. 2017. Disponível em: <https://outraspalavras.net/outrasmidias/destaque-outras-midias/a-lavajato-e-economia-devastada-tres-anos-depois/>. Acesso em: 11 abr. 2017.

KRUGMAN, P. Um basta à depressão econômica. Rio de Janeiro: Campus-Elsevier, 2012.

MARSHALL, A. Princípios de economia. v.1. São Paulo: Abril Cultural, 1985.

NBER - NATIONAL BUREAU OF ECONOMIC RESEARCH. US business cycle expansions and contractions. Cambridge, MA: NBER, 2010. Disponível em: <http://admin.nber.org/cycles/ cyclesmain.html>. Acesso em: 02 abr. 2018.

ORAIR, R. Investimento público no Brasil: trajetória e relações com o regime fiscal. Texto para discussão, IPEA, Brasília, n. 2215, 2016.

ORAIR, R.; SIQUEIRA, F.; GOBETTI, S. Política fiscal e ciclo econômico: uma análise baseada em multiplicadores do gasto público. XXI Prêmio Tesouro Nacional, Brasília: Ministério da Fazenda, 2016. Disponível em: <http://www.tesouro.fazenda.gov.br/ documents/10180/558095/2o-lugar-rodrigo-octavio-orair-086.pdf/ff2dc598-149a-419db95f-fb6e54e10d4f >. Acesso em: 25 fev. 2018.

PASSOS, A. M. Macro visão. ITAÚ-BBA, 31. mar. 2015. Disponível em: <https://www.itau.com. br/itaubba-pt/analises-economicas/publicacoes/macro-visao/declinio-secular-dascommodities-de-volta-a-tendencia>. Acesso em: 20 mar. 2018.

SICSÚ, J. O conceito de normalidade econômica marshalliano e o discricionarismo monetário de Keynes. Nova Economia, v. 9, n. 1, p. 153-170, jul., 1999. 
SINGER, A. Cutucando onças com varas curtas. Novos Estudos, Cebrap, 102. ed., v. 34, n. 2, p. 39-67, jul. 2015.

STIGLITZ, J. O mundo em queda livre. São Paulo: Companhia das Letras, 2010.

SCHUMPETER, J. Business cycles. Nova York; Londres: McGraw-Hill Book Company, 1939.

THE WORLD BANK. The World Bank Open Data. The World Bank Group [citado em 30 mai. 2018]. Disponível em: < https://data.worldbank.org/>. Acesso em: 30 mai. 2018.

UNCTAD - UNITED NATIONS CONFERENCE ON TRADE AND DEVELOPMENT. The State of Commodity Dependence. Geneva: United Nations, 2016.

VALOR. "O efeito da Lava-Jato no PIB se confirmou", diz Gesner Oliveira. Valor, 15 ago. 2016. Disponível em: <http://www.valor.com.br/valor-investe/casa-das-caldeiras/4672327/ o-efeito-da-lava-jato-no-pib-se-confirmou-diz-gesner-olivei>. Acesso em: 11 abr. 2018.

VERNON, J. R. Unemployment rates in Postbellum America: 1869-1899. Journal of Macroeconomics, v. 16, n. 4, Fall, 1994. 